\title{
Clinical Utility of Noninvasive Prenatal Screening for Rare Chromosome Abnormalities in Singleton Pregnancies
}

\author{
Ting $\mathrm{Hu}^{1}$, Jiamin Wang ${ }^{1}$, Qian $\mathrm{Zhu}^{1}$, zhu zhang ${ }^{2}$, Rui Hu${ }^{1}$, Like Xiao ${ }^{1}$, Yunyuan Yang ${ }^{1}$, \\ $\mathrm{Na} \mathrm{Liao}^{1}$, Sha Liu ${ }^{1}, \mathrm{He} \mathrm{Wang}^{1}$, Xiaoyu Niu${ }^{2}$, and Shanling Liu ${ }^{1}$ \\ ${ }^{1}$ West China Second University Hospital, Sichuan University \\ ${ }^{2}$ Sichuan University West China Second University Hospital
}

November 3, 2021

\begin{abstract}
Objective: To systematically investigate the clinical utility of noninvasive prenatal screening (NIPS) commercially used for the common fetal aneuploidies as a prenatal screening tool for rare chromosome abnormalities (RCAs). Design: Prospective study. Setting: Hospital-based. Population or Sample: 528 gravidas with positive NIPS results for RCAs. Methods: Gravidas with positive NIPS results for RCAs subsequently underwent amniocentesis for single nucleotide polymorphism array (SNP-array) were recruit. The degrees of concordance between NIPS and SNP-array were classified into full concordance, partial concordance, discordance related and discordance. Main Outcome Measures: The positive predictive values (PPVs) for rare aneuploidies and segmental imbalances, while incidental findings for regions of homozygosity/uniparental disomy (ROH/UPD), were used to evaluate the performance of NIPS. Results: Of the 528 gravidas with positive NIPS results, $29.2 \%$ were confirmed with positive prenatal SNP-array results (154/528). The PPVs for rare aneuploidies and segmental imbalances were $6.1 \%(7 / 115)$ and $21.1 \%$ (87/413), respectively. ROH/UPDs, as incidental findings, have been identified in 9.5\% (50/528) of gravidas with positive NIPS results. The PPV for clinical significant findings was $8.9 \%$ (47/528), including 7 cases with mosaic rare aneuploidies, 35 with pathogenic/likely pathogenic copy number variants, and 5 with imprinting disorders. Conclusions: NIPS commercially used for the common fetal aneuploidies yielded low PPV for rare aneuploidies, moderate PPV for segmental imbalances, and incidental findings for ROH/UPD. For the low PPV for clinical significant findings, NIPS has limited clinical utility for RCAs. Prenatal SNP-array should be regarded as the first-tier test for positive NIPS, particularly for those involved imprinted chromosomes.
\end{abstract}

\section{Clinical Utility of Noninvasive Prenatal Screening for Rare Chromosome Abnormalities in Singleton Pregnancies}

Ting $\mathrm{Hu}^{1,2,3^{*} \#}$, Jiamin Wang ${ }^{1,2,3^{*}}$, Qian $\mathrm{Zhu}^{1,2,3}$, Zhu Zhang ${ }^{1,2,3}$, Rui $\mathrm{Hu}^{1,2,3}$, Like Xiao ${ }^{1,2,3}$, Yunyuan Yang $^{1,2,3}$, Na Liao ${ }^{1,2,3}$, Sha Liu ${ }^{1,2,3}$, He Wang ${ }^{1,2,3}$, Xiaoyu Niu ${ }^{2,3 \#}$, Shanling Liu ${ }^{1,2,3 \#}$

1 Department of Medical Genetics, West China Second University Hospital, Sichuan University, Chengdu, Sichuan, 610041, China

2 Department of Obstetrics and Gynecology, West China Second University Hospital, Sichuan University, Chengdu, Sichuan, 610041, China

3 Key Laboratory of Birth Defects and Related Diseases of Women and Children(Sichuan University), Ministry of Education, Chengdu, 610041, China

* Ting Hu and Jiamin Wang contributed equally.

\# Ting Hu, Xiaoyu Niu and Shanling Liu contributed equally.

\# Corresponding author: 
Ting Hu, E-mail: huting4123@163.com

Xiaoyu Niu, E-mail: niuxy@scu.edu.cn

Shanling Liu, E-mail:

sunny630@126.com

Address: No. 20, Section 3, Renminnan Road, Chengdu, Sichuan, 610041, China

Short Title: NIPS for rare chromosome abnormalities

\section{ABSTRACT}

Objective: To systematically investigate the clinical utility of noninvasive prenatal screening (NIPS) commercially used for the common fetal aneuploidies as a prenatal screening tool for rare chromosome abnormalities (RCAs).

Design: Prospective study.

Setting: Hospital-based.

Population or Sample: 528 gravidas with positive NIPS results for RCAs.

Methods: Gravidas with positive NIPS results for RCAs subsequently underwent amniocentesis for single nucleotide polymorphism array (SNP-array) were recruit. The degrees of concordance between NIPS and SNP-array were classified into full concordance, partial concordance, discordance related and discordance.

Main Outcome Measures: The positive predictive values (PPVs) for rare aneuploidies and segmental imbalances, while incidental findings for regions of homozygosity/uniparental disomy (ROH/UPD), were used to evaluate the performance of NIPS.

Results: Of the 528 gravidas with positive NIPS results, $29.2 \%$ were confirmed with positive prenatal SNParray results (154/528). The PPVs for rare aneuploidies and segmental imbalances were $6.1 \%(7 / 115)$ and $21.1 \%$ (87/413), respectively. ROH/UPDs, as incidental findings, have been identified in $9.5 \%(50 / 528)$ of gravidas with positive NIPS results. The PPV for clinical significant findings was $8.9 \%(47 / 528)$, including 7 cases with mosaic rare aneuploidies, 35 with pathogenic/likely pathogenic copy number variants, and 5 with imprinting disorders.

Conclusions: NIPS commercially used for the common fetal aneuploidies yielded low PPV for rare aneuploidies, moderate PPV for segmental imbalances, and incidental findings for ROH/UPD. For the low PPV for clinical significant findings, NIPS has limited clinical utility for RCAs. Prenatal SNP-array should be regarded as the first-tier test for positive NIPS, particularly for those involved imprinted chromosomes.

\section{Key Words:}

Chromosomal microarray analysis; Noninvasive prenatal screening; Prenatal diagnosis; Rare aneuploidy; Rare chromosomal abnormality; Regions of homozygosity; Segmental imbalance; Uniparental disomy

\section{INTRODUCTION}

Noninvasive prenatal screening (NIPS), also referred to as cell-free fetal DNA (cff-DNA) testing, mainly based on massively parallel sequencing (MPS), has been available to screen for the common fetal aneuploidies in more than 60 countries since 2011[1]. NIPS was highly sensitive and specific for detection of trisomy 13, 18, and 21[2,3], which led to a reduction in invasive diagnostic testing requests by up to $40 \%$ to avoid procedurerelated miscarriage risk[4]. Recently, rare autosomal trisomies, well-known microdeletion/microduplication syndromes (MMS), as well as genome-wide copy number variants (CNVs), have been added by some laboratories as expanded screening items[5-7]. However, while the primary source of cff-DNA in the maternal circulation is apoptosis of placental cells from the cytotrophoblast [8,9], mixed with maternal cell-free DNA, various factors affect the accuracy of NIPS results, including confined placental mosaicism (CPM), maternal 
genomic contribution[10]. Thus, all patients with positive NIPS results should be confirmed by invasive diagnostic testing $[11,12]$.

Chromosomal microarray analysis (CMA), a high-resolution genomic technology to detect CNVs, has been recommended as a first-tier test for postnatal evaluation of individuals with unexplained developmental delay, intellectual disability, autism spectrum disorders, or multiple congenital anomalies, as well as for prenatal evaluation of fetuses with structural anomalies observed by ultrasound[13-15]. Furthermore, singlenucleotide polymorphism (SNP) array can additionally identify haploidy, triploidy, and regions of homozygosity (ROH) [16]. The pathogenesis of ROH includes imprinting effects caused by uniparental disomy (UPD)[17], as well as increased susceptibility to complex diseases caused by homozygous mutations of autosomal-recessive genes[18,19].

Several studies expanded the utility of NIPS for specific MMS, including DiGeorge syndrome (DGS), PraderWilli/Angleman syndrome (PWS/AS), cri du chat (CDC), and 1p36 microdeletion (1p36 del) syndrome with moderate to high positive predictive values (PPVs) for these diseases[20-23]. However, there is still a paucity of research focusing on rare chromosome abnormalities (RCAs) detected by NIPS commercially used for the common fetal aneuploidies. In this study, we conducted a prospective study to systematically evaluate the clinical utility of NIPS as a prenatal screening tool for detection of RCAs, including aneuploidies, segmental imbalances and $\mathrm{ROH} / \mathrm{UPD}$, for a cohort of 158,919 singleton pregnancies.

\section{MATERIALS AND METHODS}

\section{Patients}

From January 2016 to December 2020, singleton pregnancy cases at a tertiary level referral center (West China Second University Hospital, Sichuan University) were recruited for this study. Pretest counseling was performed by trained clinical geneticists. Prior to NIPS or SNP-array analysis, written informed consent was obtained from all gravidas, who agreed to be subjected to NIPS or consecutive amniocentesis due to positive NIPS results. The study was approved by the Medical Ethics Committee of West China Second University Hospital.

For NIPS, inclusion criteria were as follows: (1) advanced maternal age (AMA, [?]35 years) declined invasive procedure; (2) high risk for first or second trimester maternal serum screening (T21 [?]1/270, T18 [?]1/350) declined invasive procedure; (3) intermediate risk for maternal serum screening (T21: 1/270 1/1000, T18: 1/350 1/1000); (4) fetuses with soft markers detected by ultrasound, including nuchal translucency (NT) $>2.5 \mathrm{~mm}$; (5) positive family history, such as affected offsprings with Down syndrome; (6) pregnancies had no clinical indications. Exclusion criteria were as follows according to current standard practice in China: (1) pregnancy gestation period $<12$ weeks; (2) fetal structural anomalies detected by ultrasound before NIPS; (3) pregnant women with chromosomal abnormalities; (4) multiple pregnancies or co-twin's demise after 12 weeks; (5) pregnant women who have received stem cell therapy, transplant surgery, allogeneic blood products or immunotherapy with 1 year; (6) pregnant women with malignant tumor. A total of $10 \mathrm{ml}$ blood samples from gravidas were collected in Cell-Free DNA BCT tubes (Streck, Omaha, USA).

All gravidas with positive NIPS results for RCAs, including rare aneuploidies and segmental imbalances, were advised to perform amniocentesis for SNP-array experiments after 16 gestational weeks. Exclusion criteria were as follows: (1) positive NIPS results for common trisomies (T21/T18/T13); (2) positive NIPS results for sex chromosome aneuploidies (SCAs); (3) fetal structural anomalies detected by ultrasound before amniocentesis; (4) pregnant women who declined amniocentesis or who underwent amniocentesis for traditional cytogenetics (e.g. karyotype alone) but declined SNP-array analysis. A total of $20 \mathrm{ml}$ fetal samples were obtained through amniocentesis. Clear amniotic fluid samples were tested directly while blood-stained amniotic fluid samples were cultured before SNP-array experiments. Additionally, peripheral blood samples of the parents were obtained to confirm the fetal CNVs that were inherited or de novo, and separate $\mathrm{ROH}$ into UPD or consanguinity.

\section{Noninvasive prenatal screening}


Plasma of blood samples was isolated within $24 \mathrm{~h}$ with a two-step centrifugation. The procedures including cell-free DNA extraction, purification, library construction, and quantification were using the fetal chromosome aneuploidy (T21/T18/T13) test kit (Berry Genomics, Beijing, China). Massively parallel sequencing was performed on the NextSeq CN500 platform (Illumina) with 36-bp single-end reads, resulting in $5 \mathrm{Mb}$ total reads, which corresponds to $0.05 \times$ human genome depth. GC-bias were eliminated by using bioinformatics methods combined with a local weighted polynomial regression. Raw reads were aligned to the human reference genome GRCh37 (hg19). Each chromosome with an absolute value of Z-score greater than 3 was marked with chromosome aneuploidies. CNVs were detected using RUPA algorithm developed by Berry Genomics.

\section{Chromosomal microarray analysis}

This procedure was described in our previous study[24]. While the limit with which CMA can be expected to detect low-level mosaicism is $10^{\sim} 20 \%$ [25-27], we simultaneously performed fluorescence in situ hybridization analysis (FISH) when mosaicism ([?]10\%) was detected by CMA.

\section{Data analysis}

Positive results of NIPS for rare RCAs were classified into 2 groups: (1) rare aneuploidies, and (2) segmental imbalances, while positive results of CMA were classified into 3 groups: (1) rare aneuploidies (including mosaic aneuploidies), (2) segmental imbalances, (3) ROH/UPD. Furthermore, segmental imbalances detected by CMA were divided into groups with $\mathrm{CNV}$ sizes $<5 \mathrm{Mb}, 5^{\sim} 10 \mathrm{Mb}$, and $>10 \mathrm{Mb}$.

The NIPS results were compared with those of CMA. The compared results were classified into 4 categories: (1) Full concordance: those with consistent aneuploidy results, or with consistent chromosome arm and copy number gain/loss between NIPS and CMA; (2) Partial concordance: at least one of the findings was consistent but additional findings were detected only by one platform (NIPS/CMA) (For example, NIPS is positive for 20p duplication, CMA detected 20p13p12.1 duplication and 9p24.3p23 deletion); (3) Discordance, related: aneuploidies or segmental imbalances detected by NIPS but ROH/UPD confirmed by CMA; (4) Discordance: none of the findings detected by NIPS and CMA were consistent (For example, 1. NIPS is positive for T6, CMA with negative result; or 2.NIPS is positive for T7, CMA detected 16p11.2 deletion).

\section{Clinical follow-up assessments}

Clinical follow-up assessments were performed on all gravidas underwent amniocentesis for SNP-array analysis. This procedure was described in our previous study[24].

\section{Statistical analysis}

Statistical analysis was performed using the SPSS Statistics software v24.0 (IBM SPSS, Armonk, NY, USA). Continuous variables were compared with the Student's $t$-test, and categorical variables were compared with the use of chi-square or Fisher exact analysis, as appropriate. A $p$-value $<0.05$ was considered to indicate statistical significance.

\section{RESULTS}

\section{Patient characteristics}

A total of 158,919 gravidas were recruited to perform NIPS in the 5-year-period prospective study to evaluate the clinical value of NIPS for rare RCAs, including aneuploidies, segmental imbalances and ROH/UPD. Test failed in 95 cases, with a failure rate of $0.1 \%$. After excluding $508(0.3 \%)$ cases with screen positive results for common trisomies (T21/T18/T13) and 921 (0.6\%) cases for SCAs, in the $842(0.5 \%)$ gravidas with screen positive results for RCAs, 528 gravidas were obtained consecutive amniocentesis for SNP-array experiments. The study flow diagram is illustrated in Figure 1. The maternal age ranged from 17 to 44 years (29.1+4.7 years), $13.8 \%$ (73/528) of the gravidas were of advanced maternal age, and the gestational age for amniocentesis ranged from 17 to $30^{+1}$ weeks $(20.5+-3.3$ weeks). 
Of the 528 positive NIPS results, there were 115 fetuses at high risk for rare aneuploidies, including 10 fetuses involved multiple chromosomes, while the remaining 413 fetuses were at high risk for segmental imbalances, including 16 fetuses involved multiple chromosomes. The SNP-array was successfully performed in all gravidas, while $154(29.2 \%)$ cases were with positive results, including $7(4.5 \%, 7 / 154)$ fetuses with mosaic rare aneuploidies, $97(63.0 \%, 97 / 154)$ fetuses with segmental imbalances and $50(32.5 \%, 50 / 154)$ fetuses with UPD/ROH (Table 1). Concordance between RCAs detected by NIPS and consecutive CMA results was shown in Table 2. No significant difference in maternal age was observed between positive and negetive SNP-array group (28.8+-5.1 years vs $29.2+-4.5, P=0.350)$.

\section{Rare aneuploidies}

In our study, all the rare aneuploidies were confirmed to be mosaicism by SNP-array, accounted for $1.3 \%$ $(7 / 528)$ of positive NIPS results with full concordance (Table 2). The most common aneuploidy was mosaic trisomy 9 , while the 5 cases with the mosaic proportion ranged from $15 \%$ to $29 \%$. The other 2 cases were mosaic trisomy $15(26 \%)$ and mosaic trisomy $16(13 \%)$. All the mosaic aneuploiedies were simultaneously confirmed by FISH on amniotic fluid. Thus, the PPV for rare aneuploidies was $6.1 \%(7 / 115,95 \%$ confidence intervals (CI), $1.7 \%-10.5 \%$ ).

\section{Segmental imbalances}

A total of 111 segmental imbalances were detected by SNP-array in 18.4\% (97/528) cases with positive NIPS results, including 14 gravidas with multiple CNVs. There were 37 clinical significant CNVs involved 21 pathogenic (P) CNVs and 16 likely pathogenic (LP) CNVs, accounted for $33.3 \%$ of segmental imbalances $(37 / 111)$, with the concordant rate of $78.4 \%$ (29/37). Approximate $57.7 \%(64 / 111)$ of CNVs were $<5 \mathrm{Mb}$, $19.8 \%(22 / 111)$ were ranged from 5 to $10 \mathrm{Mb}$, and $22.5 \%$ (25/111) were $>10 \mathrm{Mb}$, with the concordant rate of $75.0 \%(48 / 64), 86.4 \%(19 / 22)$, and $88.0 \%(22 / 25)$ between NIPS and SNP-array, respectively $(P=0.276)$.

Parental confirmations by SNP-array were performed in $55.7 \%$ (54/97) cases while fetuses were detected with segmental imbalances by CMA, including 34 cases with maternal inheritance, 3 cases with paternal inheritance and 17 cases in de novo manner. The proportion of full concordance between NIPS and CMA in cases with maternally inherited CNVs was significantly higher than those with paternally inherited orde novo CNVs $(85.3 \%(29 / 34)$ vs $55.0 \%(11 / 20), P=0.014)$.

The PPV for segmental imbalances was 21.1\% (87/413, 95\% CI, 17.1\% - 25.0\%), composing of the full concordance rate between NIPS and CMA with $18.2 \%$ (75/413, 95\% CI, $14.4 \%$ - 21.9\%), and the partial concordance rate with $2.9 \%(12 / 413,95 \%$ CI, $1.3 \%-4.5 \%)$. The details of segmental imbalances detected by SNP-array were shown in Table 3.

For cases with clinical significant CNVs, the PPV was only $7.0 \%$ (29/413, 95\% CI, $4.5 \%$ - 9.5\%). For those well-known MMS[20] confirmed by SNP-array, 50\% (2/4) of CDC, all DGS, 22q11.2 duplication and 15q11q13 (PWS/AS) duplication were detected, however, 1p36 deletion was ignored by NIPS. There were 3 clinical significant CNVs associated with regions, for which variable expressivity has been demonstrated with incomplete penetrance ranged from $13.1 \%$ to $36.9 \%$ [28], including deletion of 1q21.1 recurrent region (BP3_BP4 distal)(includes GJA5), deletion of 16p13.11 recurrent region (BP2_BP3)(includes MYH11), and duplication of 22q11.2 recurrent (DGS/VCFS) region (proximal A_B)(includes TBX1).

In addition, For the 10 cases with submicroscopic unbalance rearrangements, except 1 couple refused to perform karyotyping of themselves (No.84), there were 6 cases inherited from parental balanced translocations (No.78-79,81,83,86-87), 1 case inherited from paternal pericentric invertion (No.77), and 2 cases inherited from mother with intellectual disability who was confirmed with derivative chromosome associated with her fetus (No.80,82).

\section{Regions of homozygosity/ uniparental disomy}

We incidentally detected 50 (9.5\%) fetuses with $\mathrm{ROH}$ larger than $10 \mathrm{Mb}$, while all the findings by SNP-array was relatively consistent with NIPS results, what was mentioned as aneuploidy or segmental imbalance in 
the same chromosome. ROHs were observed on autosomes, and chromosome 16 was most frequently involved (9 cases), subsequently with chromosome 1, 2, 6 (6 cases). None of these fetuses was from consanguineous couples.

In total, 30 cases were confirmed as UPD: 19 cases diagnosed with isodisomy as ROHs detected by SNP-array involved the whole chromosome, including 7 cases confirmed the source of ROHs by parental confirmations; all the 11 cases with iso-heterodisomy were verified by parental blood samples. The most frequent UPD was UPD6 (6 cases), subsequently with UPD4 (4 cases), thirdly with UPD1, UPD2 and UPD16 (3 cases).

There were 21 cases with ROHs associated with imprinted chromosomes. Except 4 couples refused to perform parental confirmations, 5 of the 17 cases was confirmed with imprinting disorders, including Transient Neonatal Diabetes mellitus (pUPD6), Silver-Russell syndrome (mUPD11), Beckwith-Wiedemann syndrome (pUPD11), Temple syndrome (mUPD14) and PWS (mUPD15). The details of ROHs detected by SNP-array were shown in Table 4.

\section{Clinical follow-up assessments}

Clinical follow-up results were obtained for $90.2 \%$ cases (476/528). Except fetuses lost of follow-up, the rates of normal infant, termination of pregnancy (TOP), and birth with defects (including neonatal demises without physical birth defects) without chromosomal aberrations by SNP-array were $94.9 \%(314 / 331), 2.4 \%$ $(8 / 331)$, and $2.7 \%$ (9/331), while in those with positive results were $49.7 \%(72 / 145), 46.9 \%(68 / 145)$, and $3.4 \%(5 / 145)$, respectively (Table 5$)$.

For the 7 fetuses confirmed with mosaic rare aneuploidies, although no significant ultrasound abnormalities were detected, all these families opted for TOP. For the 97 cases with segmental imbalances, except $5(5.2 \%)$ cases lost during at follow-up, the rate of elective TOP in fetuses with P/LP CNVs $(74.3 \%, 26 / 35)$ was significantly higher than those with uncertain clinical significance (VUS) $(12.9 \%, 8 / 62)(P<0.001)$. Except for 1 fetus treated with TOP due to ultrasound abnormalities, none of the remaining 7 fetuses with VUS were inherited CNVs. The portion of TOP for fetuses with VUS of de novo or refused parental confirmations $(25.9 \%, 7 / 27)$ was significantly higher than those with inherited VUS $(0.0 \%, 0 / 30)(P=0.010)$. For the 50 cases with ROHs, except $4(8.0 \%)$ cases lost at follow-up, the rate of elective TOP in fetuses with UPD $(75.9 \%, 22 / 29)$ was significantly higher than those with ROHs $(35.3 \%, 6 / 17)(P<0.001)$. There was no significant difference in the rate of elective TOP between fetuses UPD related imprinting disorders $(100.0 \%$, $5 / 5)$ and those with UPD unrelated imprinting disorders $(70.8 \%, 17 / 24)(P=0.222)$. The foremost reason for elective TOP in fetuses with UPD unrelated imprinting disorders was fetal growth restriction (FGR) $(29.4 \%, 5 / 17)$.

\section{DISCUSSION}

\section{Main Findings}

The screen positive rate of NIPS for RCAs was $0.5 \%(842 / 158,824)$. For the 528 gravidas underwent amniocentesis for SNP-array, NIPS demonstrated low PPV for rare aneuploidies $(6.1 \%, 7 / 115)$, and moderate PPV for segmental imbalances $(21.1 \%, 87 / 413)$. In addition, ROH/UPDs were related findings associated with positive NIPS results, with the detection rate of $9.5 \%(50 / 528)$.

The PPV for clinical significant findings was low $(8.9 \%, 47 / 528)$, including 7 cases with mosaic rare aneuploidies, 35 with pathogenic/likely pathogenic copy number variants, and 5 with imprinting disorders.

Based on chromosome distributions, the PPV for chromosome 6 in our study was high (87.5\%), followed by moderate PPVs for chromosome 12, 22, 5, 16, 1 ranged from $57.1 \%$ to $43.8 \%$. There were $20.5 \%(108 / 528)$ gravidas detected with positive NIPS results for chromosoome 7, however, the PPV was extremely low (8.3\%, 9/108).

\section{Strengths and Limitations}

The significant strength of our study is the large size of the cohort, which enables to perform subgroup 
analyses to pick up RCAs including aneuploidies, segmental imbalances and ROH/UPD. Those positive NIPS were compared to the SNP-array results from amniocentesis to determine concordance and PPV. While the challenges of expanding the scope of NIPS evaluations are widely discussed, our data are valuable in charting a path forward for patient care.

There are several limitations in our study. Firstly, we expended the clinical utility of NIPS for RCAs, which was worldwide recommended to screen for traditionally screened aneuploidies. The low depth of sequencing influences the PPVs for RCAs compared to NIPS-Plus. Secondly, our study only included gravidas with positive NIPS results of RCAs who subsequently underwent amniocentesis for SNP-array. We did not followed up those gravaidas with negative NIPS results or refused invasive procedures. Thus, we failed to obtain negative predictive value to comprehensively assess clinical utility of NIPS for RCAs. Thirdly, for the cases with negative CMA results, we did not further obtain maternal or placental results to assess the potential proportion to induce unnecessary invasive procedures. Fourthly, for those fetuses with UPD/ROHs, although parental consanguinity was excluded, autosomal recessive disorders, which were associated with ROHs, were not detect regularly.

\section{Interpretation}

Currently, NIPS has been widely used for detection of common fetal aneuploidies as well as SCAs, however, expanding the clinical applications to rare RCAs is still controversial $[29,30]$. According to the current guidelines[31,32], NIPS is not recommended to screen for rare aneuploidies and genome-wide CNVs because the screening accuracy with regard to detection and false-positive rate is not established. The PPVs for these disorders are much lower than for common trisomies, which may lead to unnecessary invasive procedures[28]. In this study, we conducted a prospective study to evaluate the clinical value of NIPS as a prenatal screening tool for RCAs.

Our study showed that the PPV for rare aneuploidies was low (6.1\%), which was consistent with previous studies[33,34]. A possible explanation for the high false positive rate is that these rare aneuploidies are less prevalent, while many of which have high rates of CPM whereby a chromosomal abnormality occurs only in the placenta but not in the fetus, with the incidence of around 1-2\% in typical CVS[12,34-36]. Interestingly, all the aneuploidies were confirmed to be low-level mosaicisms (13\% 29\%) by SNP-array on amniotic fluid, arising from mitotic rescue of a meiotic error or a very early mitotic error[37], which was consistent with previous studies[20,33]. The explainable reason is that cases with RCAs almost all experienced pregnancy loss before amniocentesis, which were excluded from our study. In addition, all the parents decided to terminate the pregnancies even though no significant ultrasound abnormality was detected, which may induce bias to comprehensively evaluate the clinical value of NIPS for rare aneuploidies especially for low-level mosaicisms without postnatal clinical features.

The PPV for segmental imbalances was moderate (21.1\%), consistent with studies of Zhu et al (28.9\%)[33] and Chen et al(29.0\%)[34], but extremely lower than Liang et al(40.8\%)[20]. The depth of sequencing may be attributable to the difference as the Liang et al [20] performed NIPS-Plus with $20 \mathrm{Mb}$ reads per sample, which was approximate 4 times our data. Additionally, NIPS-Plus used combinatorial data analysis algorithms to additionally call genome-wide CNVs associated with MMS[20]. We detected most of the well-known MMS (DGS, 22q11.22 microduplication, PWS/AS and CDC) recommended by NIPS-Plus with moderate to high PPVs [20]. However, the positions of CNVs detected by NIPS in our study could only be located to the chromosome arms, while NIPS-Plus was able to locate the cytobands and co-ordinates of CNVs. No matter NIPS or NIPS-Plus, the techniques have limited power in regions with high repeat content, thus some MMS, such as 1q21.1 recurrent microduplication/microdeletion, 16p13.11 recurrent microduplication/microdeletion, 16p11.2 microduplication/microdeletion, were susceptible to be ignored, even though the prevalence of which was similar to those well-known MMS recommended by NIPS-Plus.

In our study, compared the results of NIPS to SNP-array, there was no significant difference among the concordant rates for subgroups of $\mathrm{CNVs}<5 \mathrm{Mb}(75.0 \%)$, ranged from 5 to $10 \mathrm{Mb}$ (86.4\%), and $>10 \mathrm{Mb}$ $(88.0 \%)$. The results opposes to the empirical hypothesis that NIPS yielded a higher positive rate for larger 
segmental imbalances than smaller ones. This could be attributed to optimization and validation of regions of well-known MMS. It is exemplified that all the 4 detected CNVs involved 22q11.2 recurrent (DGS/VCFS) region in our study were less than $3.5 \mathrm{Mb}$, which was consistent to previous studies[33,38,39]. For the full concordant segmental imbalances between NIPS and SNP-array, parental confirmations showed that the rate of maternally inherited CNVs $(72.5 \%, 29 / 40)$ was significantly higher than those with paternal inheritance or in de novo manner $(27.5 \%, 11 / 40)$. Thus, it is reasonable to suspect that for gravidas with positive NIPS but negative CMA results of segmental imbalances, maternal CNVs may be detected, which also could reduce the PPVs of NIPS. Although confirmatory chromosome testing was not performed for all those gravidas in our study, it has been reported by Kaseniit et al in a large-scale study[40].

For cases with clinical significant CNVs, the PPV was only 7.0\% (29/413). Except 9 cases with parental chromosome rearrangements, the PPVs for clinical significant CNVs was extremely low (4.8\%, 20/413). All the fetuses with parental-inherited VUS, even with incomplete penetrant $\mathrm{P} / \mathrm{LP} \mathrm{CNVs}$, were born, however, $46.4 \%$ (45/97) families refused parental confirmations, 2 of which opted for TOP. VUS accounted for $63.9 \%$ (62/97) of imbalanced segments in our study, thus, the detection of VUS following positive NIPS is bound to accompany with increased family economic burden, maternal anxiety or even panic, and potential risk to terminate pregnancy. It should be prudent whether NIPS is an effective way to screen for clinical significant CNVs.

ROHs, termed as copy number neutral segments showing continuous homozygosity with no intervening heterozygosity[41], were incidental findings (9.5\%) in our study, while the NIPS results involved aneuploidies or segmental imbalances related to the chromosome. Consistent to previous studies[42,43], as we excluded positive NIPS results from sex chromosomes, ROHs most frequently involved chromosome 16 and 2, followed by chromosome 1 and 6 . UPD is defined as both homologous chromosomes are inherited from one parent, with no contribution (for that chromosome) from the other parent[44]. The common mechanisms resulting in UPD involving trisomy rescue, monosomy rescue, and somatic mitotic crossing over[45]. After further parental confirmation, $60.0 \% \mathrm{ROH}$ were diagnosed as UPD, with maternal to paternal rate of 14:4, which is consistent to previous studies due to the higher propensity for maternal non-disjunction[46,47]. Thus, we recommend prenatal SNP-array for gravidas with positive NIPS results of RCAs, especially for those involved imprinted chromosomes.

Benefit from the incidental findings of NIPS, 5 fetuses with imprinting disorders were detected. As the results of prenatal diagnosis were obtained before detailed second trimester fetal anomaly scans, these families opted for TOP prior to typical ultrasound presentation of these disorders were shown. While imprinting disorders were excluded, UPD is almost without clinical consequence[45]. However, it was reported that ROH/UPD fetuses with ultrasound abnormalities showed worse prognoses than those without abnormalities[42]. In our study, $12.0 \%$ (6/50) cases showed FGR, one of the common ultrasound abnormalities for fetuses with $\mathrm{ROH} / \mathrm{UPD}$, which indicated for adverse perinatal outcomes, and those families opted for TOP. Interestingly, the fetus (No.123) with mUPD15 and fetus (No.126) with mUPD16 was subsequently confirmed with placental trisomy 15 and trisomy 16, respectively, which further verified the mechanism of CPM.

\section{CONCLUSIONS}

In summary, this prospective study demonstrates that NIPS commercially used for the common fetal aneuploidies yielded low PPV for rare aneuploidies (6.1\%), moderate PPV for segmental imbalances (21.1\%), and incidental findings $(9.5 \%)$ for ROH/UPD. This study provided valuable information for genetic counselling and management of gravidas with positive NIPS results of RCAs. For the low PPV for clinical significant findings, NIPS has limited clinical utility for rare RCAs. Prenatal SNP-array should be regarded as the first-tier test for positive NIPS, particularly for those involved imprinted chromosomes.

\section{ACKNOWLEDGEMENTS}

This work was supported by National Key Research and Development Program of China (2021YFC1005304) and Technology Research and Development Program of Science and Technology Department of Sichuan Province, China (2021YFS0078). 


\section{DISCLOSURE OF INTERESTS}

The authors report no conflict of interest.

\section{Contribution to authorship}

The study was conceived and designed by TH, HW, XN and SL. Patient recruitment and sample collection were under taken by TH and JW. Experiments and data collection were performed by TH, JW, RH, LX, NL and SL. Data analyses and interpretation were performed by TH, JW, QZ and ZZ. All figures and tables were generated by TH and JW. The manuscript was written by TH and JW. All authors critically reviewed the manuscript and approved the final manuscript for publication.

\section{Details of ethics approval}

The study was approved by the Medical Ethics Committee of West China Second University Hospital (IRB no. 20160029, approval date 28 December 2016).

\section{Funding}

This work was supported by the National Key Research and Development Program of China (2021YFC1005304) and Technology Research and Development Program of Science and Technology Department of Sichuan Province, China (2021YFS0078).

\section{Acknowledgements}

We would like to thank all doctors who helped with patient recruitment. We are grateful to all the team members for their contributions to data collection and integrity.

\section{REFERENCES}

1. Palomaki GE, Kloza EM, Lambert-Messerlian GM, Haddow JE, Neveux LM, Ehrich M,et al. DNA sequencing of maternal plasma to detect Down syndrome: an international clinical validation study. Genet Med. 2011;13(11):913-920.

2. Committee Opinion No. 640: Cell-Free DNA Screening For Fetal Aneuploidy. Obstet Gynecol. 2015;126(3):e31-e37.

3. Taylor-Phillips S, Freeman K, Geppert J, Agbebiyi A, Uthman OA, Madan J, et al. Accuracy of noninvasive prenatal testing using cell-free DNA for detection of Down, Edwards and Patau syndromes: a systematic review and meta-analysis. BMJ Open. 2016 Jan 18;6(1):e010002.

4. Wong FC, Lo YM. Prenatal diagnosis innovation: genome sequencing of maternal plasma. Annu Rev Med. 2016;67:419-432.

5. Wapner RJ, Babiarz JE, Levy B, Stosic M, Zimmermann B, Sigurjonsson S,et al. Expanding the scope of noninvasive prenatal testing: detection of fetal microdeletion syndromes. Am J Obstet Gynecol. 2015;212(3):332.e1-9.

6. Benn P, Grati FR. Genome-wide non-invasive prenatal screening for all cytogenetically visible imbalances. Ultrasound Obstet Gynecol. 2018;51(4):429-433.

7. Wapner RJ, Martin CL, Levy B, Ballif BC, Eng CM, Zachary JM,et al. Chromosomal microarray versus karyotyping for prenatal diagnosis. N Engl J Med. 2012;367(23):2175-2184.

8. Tjoa ML, Cindrova-Davies T, Spasic-Boskovic O, Bianchi DW, Burton GJ. Trophoblastic oxidative stress and the release of cell-free feto-placental DNA. Am J Pathol.2006;169(2):400-404.

9. Faas BH, de Ligt J, Janssen I, Eggink AJ, Wijnberger LD, van Vugt JM, et al. Non-invasive prenatal diagnosis of fetal aneuploidies using massively parallel sequencing-by-ligation and evidence that cellfree fetal DNA in the maternal plasma originates from cytotrophoblastic cells. Expert Opin Biol Ther. 2012;12 Suppl 1:S19-26.

10. Bianchi DW, Wilkins-Haug L. Integration of noninvasive DNA testing for aneuploidy into prenatal care: what has happened since the rubber met the road? Clin Chem. 2014;60(1):78-87.

11. Cherry AM, Akkari YM, Barr KM, Kearney HM, Rose NC, South ST, et al. Diagnostic cytogenetic testing following positive noninvasive prenatal screening results: a clinical laboratory practice resource 
of the American College of Medical Genetics and Genomics (ACMG). Genet Med. 2017;19(8):845-850.

12. Mardy A, Wapner RJ. Confifined placental mosaicism and its impact on confifirmation of NIPT results. Am J Med Genet C Semin Med Genet. 2016;172(2):118-122.

13. Manning M, Hudgins L; Professional Practice and Guidelines Committee. Array-based technology and recommendations for utilization in medical genetics practice for detection of chromosomal abnormalities. Genet Med. 2010;12(11):742-745.

14. Miller DT, Adam MP, Aradhya S, Biesecker LG, Brothman AR, Carter NP, et al. Consensus statement: chromosomal microarray is a first-tier clinical diagnostic test for individuals with developmental disabilities or congenital anomalies. Am J Hum Genet. 2010;86(5):749-764.

15. American College of Obstetricians and Gynecologists Committee on Genetics. Committee opinion no. 581: the use of chromosomal microarray analysis in prenatal diagnosis. Obstet Gynecol. 2013;122(6):1374-1377.

16. Levy B, Sigurjonsson S, Pettersen B, Maisenbacher MK, Hall MP, Demko Z, et al. Genomic imbalance in products of conception: single-nucleotide polymorphism chromosomal microarray analysis. Obstet Gynecol. 2014;124(2 Pt 1):202-209.

17. Robinson WP. Mechanisms leading to uniparental disomy and their clinical consequences. Bioessays. 2000;22(5):452-459.

18. Campbell H, Carothers AD, Rudan I, Hayward C, Biloglav Z, Barac L, et al. Effects of genomewide heterozygosity on a range of biomedically relevant human quantitative traits. Hum Mol Genet. 2007;16(2):233-241.

19. Ku CS, Naidoo N, Teo SM, Pawitan Y. Regions of homozygosity and their impact on complex diseases and traits. Hum Genet. 2011;129(1):1-15.

20. Liang D, Cram DS, Tan H, Linpeng S, Liu Y, Sun H, et al. Clinical utility of noninvasive prenatal screening for expanded chromosome disease syndromes.Genet Med. 2019;21(9):1998-2006.

21. Dar P, Curnow KJ, Gross SJ, Hall MP, Stosic M, Demko Z, et al. Clinical experience and follow-up with large scale single-nucleotide polymorphism-based noninvasive prenatal aneuploidy testing. Am J Obstet Gynecol. 2014;211(5):527.e1-527.e17.

22. Gross SJ, Stosic M, McDonald-McGinn DM, Bassett AS, Norvez A, Dhamankar R, et al. Clinical experience with single-nucleotide polymorphism-based non-invasive prenatal screening for 22q11.2 deletion syndrome. Ultrasound Obstet Gynecol. 2016;47(2):177-183.

23. Petersen AK, Cheung SW, Smith JL, Bi W, Ward PA, Peacock S, et al. Positive predictive value estimates for cell-free noninvasive prenatal screening from data of a large referral genetic diagnostic laboratory. Am J Obstet Gynecol. 2017;217(6):691.e1-691.e6.

24. Hu T, Tian T, Zhang Z, Wang J, Hu R, Xiao L, et al. Prenatal chromosomal microarray analysis in 2466 fetuses with ultrasonographic soft markers: a prospective cohort study. Am J Obstet Gynecol. 2021;224(5):516.e1-516.e16.

25. Cross J, Peters G, Wu Z, Brohede J, Hannan GN. Resolution of trisomic mosaicism in prenatal diagnosis: estimated performance of a 50K SNP microarray. Prenat Diagn. 2007;27(13):1197-204.

26. Scott SA, Cohen N, Brandt T, Toruner G, Desnick RJ, Edelmann L. Detection of low-level mosaicism and placental mosaicism by oligonucleotide array comparative genomic hybridization. Genet Med. 2010;12(2):85-92.

27. Hall GK, Mackie FL, Hamilton S, Evans A, McMullan DJ, Williams D, et al. Chromosomal microarray analysis allows prenatal detection of low level mosaic autosomal aneuploidy. Prenat Diagn. 2014;34(5):505-7.

28. Rosenfeld JA, Coe BP, Eichler EE, Cuckle H, Shaffer LG. Estimates of penetrance for recurrent pathogenic copy-number variations. Genet Med. 2013;15(6):478-81.

29. Rose NC, Benn P, Milunsky A. Current controversies in prenatal diagnosis 1: should NIPT routinely include microdeletions/microduplications? Prenat Diagn. 2016;36(1):10-14.

30. Chitty LS, Hudgins L, Norton ME. Current controversies in prenatal diagnosis 2: Cell-free DNA prenatal screening should be used to identify all chromosome abnormalities. Prenat Diagn. 2018;38(3):160165. 
31. Gregg AR, Skotko BG, Benkendorf JL, Monaghan KG, Bajaj K, Best RG, et al. Noninvasive prenatal screening for fetal aneuploidy, 2016 update: a position statement of the American College of Medical Genetics and Genomics. Genet Med. 2016;18(10):1056-1065.

32. Screening for Fetal Chromosomal Abnormalities: ACOG Practice Bulletin, Number 226. American College of Obstetricians and Gynecologists' Committee on Practice Bulletins - Obstetrics; Committee on Genetics; Society for Maternal-Fetal Medicine. Obstet Gynecol. 2020;136(4):e48-e69.

33. Zhu X, Chen M, Wang H, Guo Y, Chau MHK, Yan H,et al. Clinical utility of expanded noninvasive prenatal screening and chromosomal microarray analysis in high-risk pregnancy. Ultrasound Obstet Gynecol. 2021;57(3):459-465.

34. Chen Y, Yu Q, Mao X, Lei W, He M, Lu W. Noninvasive prenatal testing for chromosome aneuploidies and subchromosomal microdeletions/microduplications in a cohort of 42,910 single pregnancies with different clinical Features. Hum Genomics. 2019;13(1):60.

35. Grati FR, Malvestiti F, Ferreira JC, Bajaj K, Gaetani E, Agrati C, et al. Fetoplacental mosaicism: potential implications for false-positive and false-negative noninvasive prenatal screening results. Genet Med. 2014;16(8):620-624.

36. Grati FR, Malvestiti F, Branca L, Agrati C, Maggi F, Simoni G. Chromosomal mosaicism in the fetoplacental unit. Best Practice \& Research. Best Pract Res Clin Obstet Gynaecol. 2017;42:39-52.

37. Taylor TH, Gitlin SA, Patrick JL, Crain JL, Wilson JM, Griffin DK. The origin, mechanisms, incidence and clinical consequences of chromosomal mosaicism in humans. Hum Reprod Update. 2014;20(4):571581.

38. Liang D, Cram DS, Tan H, Linpeng S, Liu Y, Sun H, et al. Clinical utility of noninvasive prenatal screening for expanded chromosome disease syndromes. Genet Med. 2019;21(9):1998-2006.

39. Ravi H, McNeill G, Goel S, Meltzer SD, Hunkapiller N, Ryan A, et al. Validation of a SNP-based non-invasive prenatal test to detect the fetal 22q11.2 deletion in maternal plasma samples. PLoS One. 2018;13(2):e0193476.

40. Kaseniit KE, Hogan GJ, D'Auria KM, Haverty C, Muzzey D. Strategies to minimize false positives and interpret novel microdeletions based on maternal copy-number variants in 87,000 noninvasive prenatal screens. BMC Med Genomics. 2018;11(1):90.

41. Broman KW, Weber JL. Long homozygous chromosomal segments in reference families from the centre d'Etude du polymorphisme humain. Am J Hum Genet. 1999;65(6):1493-1500.

42. Liu J, He Z, Lin S, Wang Y, Huang L, Huang X, et al. Absence of heterozygosity detected by singlenucleotide polymorphism array in prenatal diagnosis. Ultrasound Obstet Gynecol. 2021;57(2):314-323.

43. Wen J, Comerford K, Xu Z, Wu W, Amato K, Grommisch B, et al. Analytical validation and chromosomal distribution of regions of homozygosity by oligonucleotide array comparative genomic hybridization from normal prenatal and postnatal case series. Mol Cytogenet. 2019;12:12.

44. Engel E. A new genetic concept: uniparental disomy and its potential effect, the isodisomy. Am J Med Genet. 1980;6(2):137-143.

45. Del Gaudio D, Shinawi M, Astbury C, Tayeh MK, Deak KL, Raca G; ACMG Laboratory Quality Assurance Committee.Diagnostic testing for uniparental disomy: a points to consider statement from the American College of Medical Genetics and Genomics (ACMG). Genet Med. 2020;22(7):1133-1141.

46. Liehr T. Cytogenetic contribution to uniparental disomy (UPD). Mol Cytogenet. 2010;3:8.

47. Yamazawa K, Ogata T, Ferguson-Smith AC. Uniparental disomy and human disease: An overview. Am J Med Genet C Semin Med Genet. 2010;154C(3):329-334.

Table 1 Summary of the CMA results of 528 fetuses with positive NIPS results

\begin{tabular}{|c|c|c|c|c|c|c|}
\hline Chromosome & NIPS (n) & $\begin{array}{l}\text { CMA (n) } \\
\text { Rare aneuploidies }\end{array}$ & $\begin{array}{l}\text { CMA (n) } \\
\text { Segmental imbalances }\end{array}$ & $\begin{array}{l}\text { CMA (n) } \\
\text { ROH/UPD }\end{array}$ & $\begin{array}{l}\text { CMA (n) } \\
\text { Normal }\end{array}$ & PPV \\
\hline Chr1 & 16 & - & 1 & 6 & 9 & 43.8 \\
\hline Chr2 & 28 & - & 5 & 6 & 17 & 39.3, \\
\hline Chr 3 & 25 & - & 4 & 2 & 19 & 24.0, \\
\hline Chr 4 & 15 & - & 2 & 4 & 9 & 40.0 \\
\hline
\end{tabular}




\begin{tabular}{|c|c|c|c|c|c|c|}
\hline Chr 5 & 19 & - & $8(1)^{[?]}$ & - & 10 & 42.1 \\
\hline Chr 6 & 8 & - & 1 & 6 & 1 & 87.5 \\
\hline Chr 7 & 108 & - & $5(2)^{[?]}$ & 2 & 99 & $6.5,1$ \\
\hline Chr 8 & 48 & - & 8 & 5 & 35 & 27.1 \\
\hline Chr 9 & 20 & $5^{*}$ & 2 & 3 & 10 & 50.0 \\
\hline Chr 10 & 16 & - & 6 & - & 10 & 37.5 \\
\hline Chr 11 & 19 & - & $3(1)^{[?]}$ & 2 & 13 & 26.3 \\
\hline Chr 12 & 7 & - & 3 & 1 & 3 & 57.1 \\
\hline Chr 13 & 14 & - & 5 & 1 & 8 & 42.9 \\
\hline Chr 14 & 18 & - & $1(3)^{[?]}$ & 1 & 13 & 11.1, \\
\hline Chr 15 & 20 & $1^{*}$ & $5(1)^{[?]}$ & 1 & 12 & 35.0 \\
\hline Chr 16 & 33 & $1^{*}$ & 5 & 9 & 18 & 45.5 \\
\hline Chr 17 & 7 & - & 1 & 1 & 5 & 28.6 \\
\hline Chr 18 & 22 & - & $8(1)^{[?]}$ & - & 13 & 36.4 \\
\hline Chr 19 & 1 & - & - & - & 1 & - \\
\hline Chr 20 & 26 & - & 3 & - & 23 & 11.5 \\
\hline Chr 21 & 21 & - & 3 & - & 18 & 14.3 \\
\hline Chr 22 & 11 & - & 6 & - & 5 & 54.5 \\
\hline Multiple chromosome & 26 & - & $2(1)^{[?]}$ & - & 23 & $7.7,-$ : \\
\hline Total (n) & 528 & 7 & $87(10)^{[?]}$ & 50 & 374 & 27.3 \\
\hline
\end{tabular}

* mosaic aneuploidies; [?] The positive results discordant with NIPS.

NIPS: noninvasive prenatal screening; CMA: chromosomal microarray analysis;

ROH: regions of homozygosity; UPD: uniparental disomy; PPV: positive predictive value;

CI: confidence intervals

Table 2 Concordance between RCAs detected by NIPS and consecutive CMA results

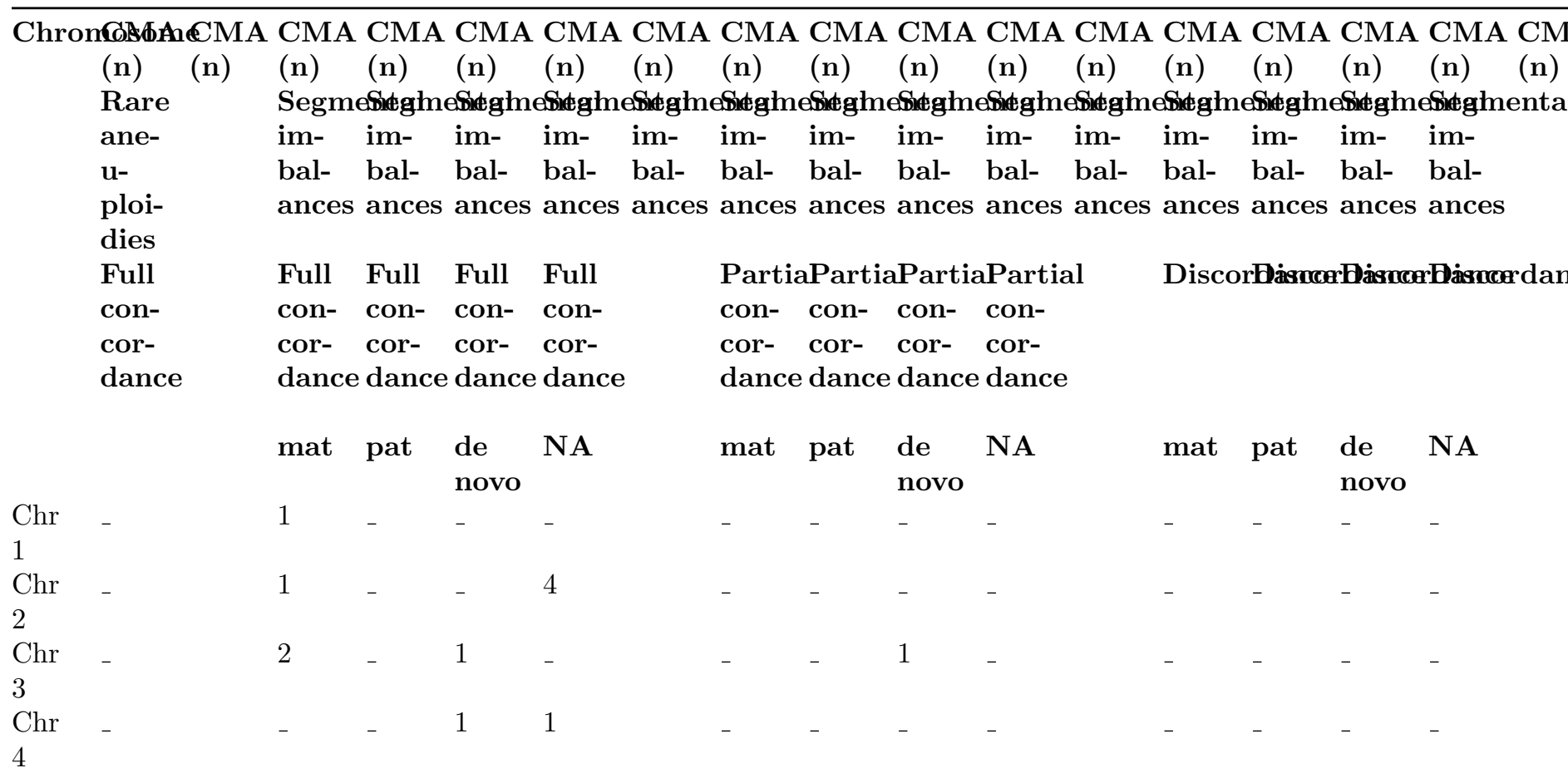




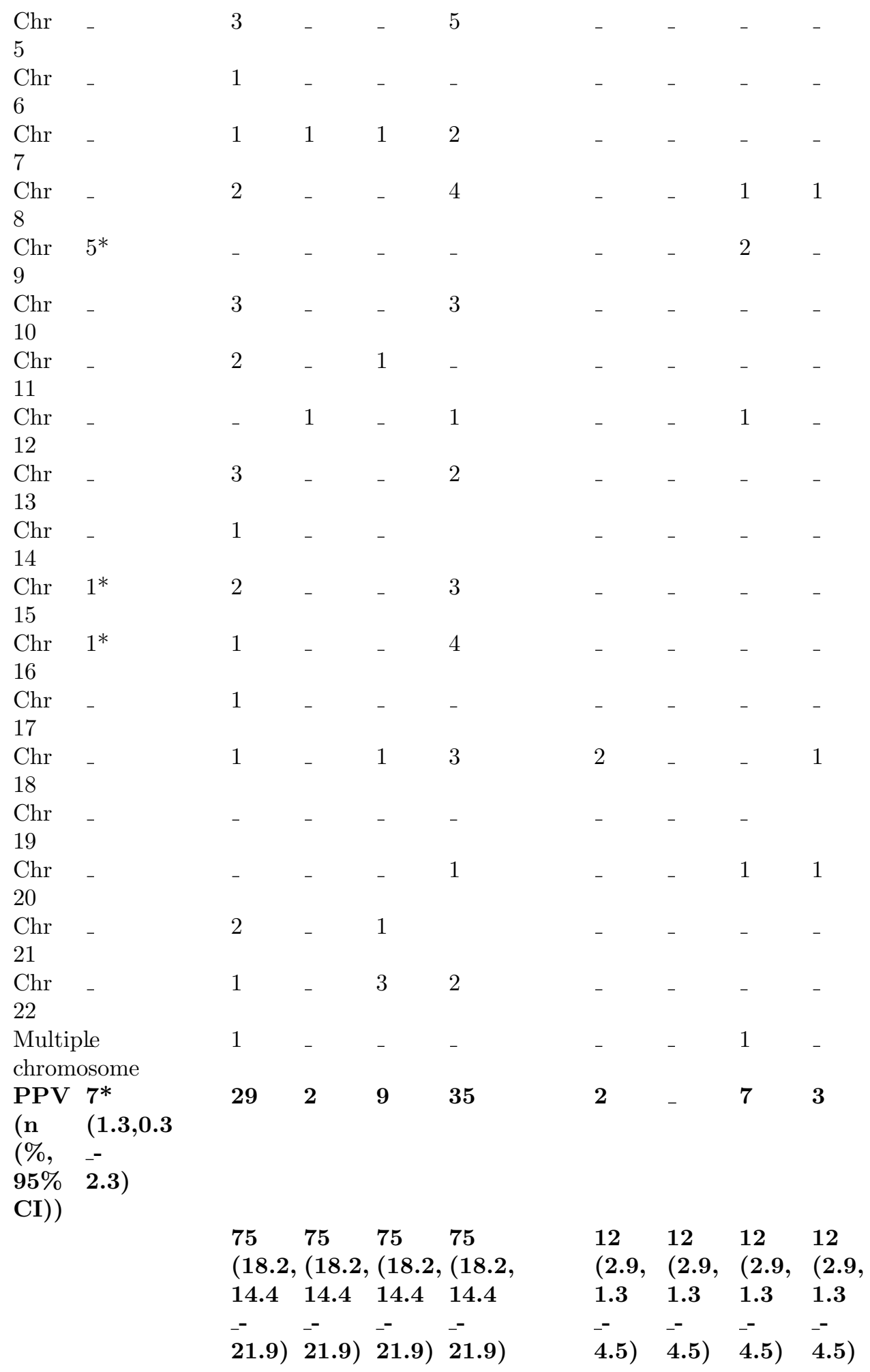




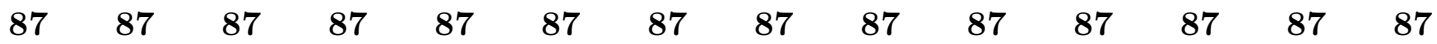

(21.1) (21.1) (21.1, (21.1) (21.1) (21.1) (21.1) (21.1, (21.1) (21.1, (21.1, (21.1) (21.1, (21.1, 17.1_- 17.1_- 17.1_- 17.1_- 17.1_- 17.1_- 17.1_- 17.1_- 17.1_- 17.1_- 17.1_- 17.1_- 17.1_- 17.1_$25.0)^{\left.\left.\left.\left.\left.\left.\left.\left.\left.\left.\left.\left.[? 25.0)^{[?} 25.0\right)^{[?} 25.0\right)^{[?} 25.0\right)^{[?} 25.0\right)^{[?} 25.0\right)^{[?} 25.0\right)^{[?} 25.0\right)^{[?} 25.0\right)^{[?} 25.0\right)^{[?} 25.0\right)^{[?} 25.0\right)^{[?} 25.0\right)^{[?]}}$

* mosaic aneuploidies; [?] The positive results discordant with NIPS.

RCAs: rare chromosome abnormalities; CMA: chromosomal microarray analysis; NA: not available; ROH: regions of homozygosity; UPD: uniparental disomy; PPV: positive predictive value; CI: confidence intervals

Table 3 Prenatal CNVs detected by CMA among the 528 gravidas with positive NIPS results

\begin{tabular}{|c|c|c|c|c|c|c|c|c|}
\hline No. & NIPS & $\begin{array}{ll}\text { CNVs } & \text { Size of } \\
(\text { GRCh37) } & \text { CNVs } \\
& (\mathrm{kb})\end{array}$ & $\begin{array}{l}\text { Copy } \\
\text { number }\end{array}$ & $\begin{array}{l}\mathrm{HI} / \mathrm{TS} \\
\text { region }\end{array}$ & $\begin{array}{l}\text { HI/TS } \\
\text { gene }\end{array}$ & $\begin{array}{l}\text { Inherited } \\
\text { or de } \\
\text { novo }\end{array}$ & $\begin{array}{l}\text { ACMG } \\
\text { Classifi- } \\
\text { cation }\end{array}$ & Outcomes \\
\hline 1 & $\begin{array}{l}\operatorname{chr} 7 p \\
\text { dup }\end{array}$ & $\begin{array}{l}7 \mathrm{p} 22.2(296653168- \\
3334799) \times 3\end{array}$ & Gain & / & / & $\mathrm{NA}$ & VUS & Born \\
\hline 2 & $\begin{array}{l}\text { chr5p } \\
\text { del }\end{array}$ & $\begin{array}{l}\text { 5p14.3(19076258_- } \\
19448955) \times 1\end{array}$ & Loss & / & / & NA & VUS & Born \\
\hline 3 & $\begin{array}{l}\operatorname{chr} 13 q \\
\text { dup }\end{array}$ & $\begin{array}{l}\text { 13q12.11(2261824245_- } \\
22999366) \times 3\end{array}$ & Gain & / & / & NA & VUS & Born \\
\hline 4 & $\begin{array}{l}\text { chr3p } \\
\text { dup }\end{array}$ & $\begin{array}{l}3 \mathrm{p} 26.2 \mathrm{p} 26.1\left(\$ 66046_{-}-\right. \\
4273489) \times 3\end{array}$ & Gain & / & / & $\begin{array}{l}\text { Inherited } \\
\text { from } \\
\text { normal } \\
\text { mother }\end{array}$ & VUS & Born \\
\hline 5 & $\begin{array}{l}\operatorname{chr} 15 q \\
\text { dup }\end{array}$ & $\begin{array}{l}\text { 15q13.3(319919832_- } \\
32428066) \times 3\end{array}$ & Gain & / & / & $\mathrm{NA}$ & VUS & Born \\
\hline 6 & $\begin{array}{l}\text { chr7q } \\
\text { del }\end{array}$ & $\begin{array}{l}\text { 7q11.21(646152380_- } \\
65148399) \times 1\end{array}$ & Loss & / & / & NA & VUS & Born \\
\hline 7 & $\begin{array}{l}\text { chr20q } \\
\text { del }\end{array}$ & $\begin{array}{l}\text { 20q13.13(46465687_- } \\
47125819) \times 1\end{array}$ & Loss & / & / & NA & VUS & Born \\
\hline 8 & $\begin{array}{l}\text { chr5p } \\
\text { dup }\end{array}$ & $\begin{array}{l}5 \mathrm{p} 15.31\left(675267577_{-}\right. \\
7429552) \times 4\end{array}$ & Gain & / & / & $\begin{array}{l}\text { Inherited } \\
\text { from } \\
\text { normal } \\
\text { mother }\end{array}$ & VUS & Born \\
\hline 9 & $\begin{array}{l}\text { chr7p } \\
\text { dup }\end{array}$ & $\begin{array}{l}\text { 7p21.1(17592B51_- } \\
\text { 18327081)x3 }\end{array}$ & Gain & / & / & $\begin{array}{l}\text { Inherited } \\
\text { from } \\
\text { normal } \\
\text { father }\end{array}$ & VUS & Born \\
\hline 10 & $\begin{array}{l}\operatorname{chr} 13 q \\
\text { dup }\end{array}$ & $\begin{array}{l}\text { 13q12.11(21550989_- } \\
21972234) \times 3\end{array}$ & Gain & / & / & NA & VUS & Born \\
\hline 11 & $\begin{array}{l}\text { chr22q } \\
\text { del }\end{array}$ & $\begin{array}{l}22 q 11.21(21069669- \\
21800471) \times 1\end{array}$ & Loss & / & / & $\begin{array}{l}\text { Inherited } \\
\text { from } \\
\text { normal } \\
\text { mother }\end{array}$ & VUS & Born \\
\hline 12 & $\begin{array}{l}\text { chr22q } \\
\text { del }\end{array}$ & $\begin{array}{l}22 \mathrm{q} 11.21(210591669- \\
21800471) \times 1\end{array}$ & Loss & / & / & $\begin{array}{l}\text { de } \\
\text { novo }\end{array}$ & VUS & TOP \\
\hline 13 & $\begin{array}{l}\operatorname{chr} 17 q \\
\text { dup }\end{array}$ & $\begin{array}{l}\text { 17q11.2(287456181_- } \\
29516669) \times 3\end{array}$ & Gain & / & / & $\begin{array}{l}\text { Inherited } \\
\text { from } \\
\text { normal } \\
\text { mother }\end{array}$ & VUS & Born \\
\hline
\end{tabular}




\begin{tabular}{|c|c|c|c|c|c|c|c|c|}
\hline 14 & $\begin{array}{l}\operatorname{chr} 18 \mathrm{p} \\
\text { dup }\end{array}$ & $\begin{array}{l}18 \mathrm{p} 11.32(125815 \text { - } \\
1802917) \times 3\end{array}$ & Gain & $15 q 133$ & / & NA & VUS & $\begin{array}{l}\text { Born } \\
\text { (Pre- } \\
\text { mature } \\
\text { delivery) }\end{array}$ \\
\hline 15 & $\begin{array}{l}\operatorname{chr} 15 q \\
\text { del }\end{array}$ & $\begin{array}{l}\text { 15q13.3(3196874T70_- } \\
\text { 32914239)x1 }\end{array}$ & Loss & $\begin{array}{l}15 q 13.3 \\
\text { recur- } \\
\text { rent } \\
\text { region } \\
\text { (D_- } \\
\text { CHRNA7 } \\
\text { to } \\
\text { BP5) } \\
\text { (in- } \\
\text { cludes } \\
\text { CHRNA7 } \\
\text { and } \\
\text { OTUD7A) }\end{array}$ & / & NA & $\mathrm{P}$ & \\
\hline 16 & $\begin{array}{l}\text { chr8q } \\
\text { dup }\end{array}$ & $\begin{array}{l}\text { 8q24.11(11791927212_- } \\
119012676) \times 3\end{array}$ & Gain & / & / & $\begin{array}{l}\text { Inherited } \\
\text { from } \\
\text { normal } \\
\text { mother }\end{array}$ & VUS & Born \\
\hline 17 & $\begin{array}{l}\operatorname{chr} 13 q \\
\text { dup }\end{array}$ & $\begin{array}{l}\text { 13q31.1(8192411890_- } \\
83110879) \times 3\end{array}$ & Gain & l & / & $\begin{array}{l}\text { Inherited } \\
\text { from } \\
\text { normal } \\
\text { mother }\end{array}$ & VUS & Born \\
\hline 18 & $\begin{array}{l}\operatorname{chr} 2 \mathrm{p} \\
\text { dup }\end{array}$ & $\begin{array}{l}\text { 2p12(7863171019 } \\
79851089) \times 4\end{array}$ & Gain & l & / & $\mathrm{NA}$ & VUS & Born \\
\hline 19 & $\begin{array}{l}\operatorname{chr} 13 \mathrm{q} \\
\text { del }\end{array}$ & $\begin{array}{l}\text { 13q12.12(2351335511_- } \\
\text { 24970361)x1 }\end{array}$ & Loss & l & / & $\begin{array}{l}\text { Inherited } \\
\text { from } \\
\text { normal } \\
\text { mother }\end{array}$ & VUS & Born \\
\hline 20 & $\begin{array}{l}\text { chr10q } \\
\text { dup }\end{array}$ & \multicolumn{2}{|c|}{$\begin{array}{l}\text { 10q24.32q25.114504583879Gain } \\
\text { 106039196)x3 }\end{array}$} & / & / & NA & VUS & Born \\
\hline 21 & $\begin{array}{l}\operatorname{chr} 13 q \\
\text { dup }\end{array}$ & $\begin{array}{l}\text { 13q32.1(9534(56374_- } \\
96874757) \times 3\end{array}$ & Gain & l & / & $\begin{array}{l}\text { Inherited } \\
\text { from } \\
\text { normal } \\
\text { mother }\end{array}$ & VUS & Born \\
\hline 22 & $\begin{array}{l}\operatorname{chr} 2 q \\
\text { del }\end{array}$ & \multicolumn{2}{|c|}{$\begin{array}{l}\text { 2q12.2q12.3(106856366_- Loss } \\
\text { 108527327)x1 }\end{array}$} & l & / & NA & VUS & Born \\
\hline 23 & $\begin{array}{l}\text { chr16p } \\
\text { dup }\end{array}$ & \multicolumn{2}{|c|}{$\begin{array}{l}\text { 16p13.12p1311776( } 4770633 \text { Gain } \\
\text { 16538596)x3 }\end{array}$} & I & / & NA & VUS & Born \\
\hline 24 & $\begin{array}{l}\operatorname{chr} 1 \mathrm{q} \\
\text { del }\end{array}$ & \multicolumn{2}{|c|}{$\begin{array}{l}\text { 1q21.1q21.2(19B706724_- Loss } \\
\text { 147933973)x1 }\end{array}$} & $\begin{array}{l}\text { 1q21.1 } \\
\text { recur- } \\
\text { rent } \\
\text { region } \\
\text { (BP3_- } \\
\text { BP4 } \\
\text { distal) } \\
\text { (in- } \\
\text { cludes } \\
\text { GJA5) }\end{array}$ & / & $\begin{array}{l}\text { Inherited } \\
\text { from } \\
\text { normal } \\
\text { mother }\end{array}$ & $\mathrm{P}$ & Born \\
\hline
\end{tabular}




\begin{tabular}{|c|c|c|c|c|c|c|c|c|}
\hline 25 & $\begin{array}{l}\text { chr8p } \\
\text { dup }\end{array}$ & $\begin{array}{l}\text { 8p23.2p23.1(11822453_- } \\
6204870) \times 3\end{array}$ & Gain & 1 & / & $\begin{array}{l}\text { Inherited } \\
\text { from } \\
\text { normal } \\
\text { mother }\end{array}$ & VUS & Born \\
\hline 26 & $\begin{array}{l}\text { chr22q } \\
\text { dup }\end{array}$ & \multicolumn{2}{|c|}{$\begin{array}{l}\text { 22q11.22q11.29622997928Gain } \\
\text { 24995256)x3 }\end{array}$} & & / & $\begin{array}{l}\text { de } \\
\text { novo }\end{array}$ & VUS & Born \\
\hline 27 & $\begin{array}{l}\operatorname{chr} 7 q \\
\text { dup }\end{array}$ & \multicolumn{2}{|c|}{$\begin{array}{l}\text { 7q11.21q11.22(86785467_Gain } \\
\text { 68970684)x4 }\end{array}$} & 1 & 1 & $\begin{array}{l}\text { Inherited } \\
\text { from } \\
\text { normal } \\
\text { mother }\end{array}$ & VUS & Born \\
\hline 28 & $\begin{array}{l}\text { chr5p } \\
\text { dup } \\
\text { chr14q } \\
\text { dup }\end{array}$ & $\begin{array}{l}\text { 5p15.31(882707192228 } \\
\text { 9798033)x3 } \\
\text { 14q31.3(85359235_- } \\
87586936) \times 4\end{array}$ & $\begin{array}{l}\text { Gain } \\
\text { Gain }\end{array}$ & $1 /$ & $1 /$ & $\begin{array}{l}\text { Inherited } \\
\text { from } \\
\text { normal } \\
\text { mother } \\
\text { Inherited } \\
\text { from } \\
\text { normal } \\
\text { mother }\end{array}$ & $\begin{array}{l}\text { VUS } \\
\text { VUS }\end{array}$ & Born \\
\hline 29 & $\begin{array}{l}\text { chr16q } \\
\text { dup }\end{array}$ & $\begin{array}{l}\text { 16q21(619960306- } \\
64301745) \times 3\end{array}$ & Gain & 1 & / & $\begin{array}{l}\text { Inherited } \\
\text { from } \\
\text { normal } \\
\text { mother }\end{array}$ & VUS & Born \\
\hline 30 & $\begin{array}{l}\text { chr22q } \\
\text { del }\end{array}$ & $\begin{array}{l}\text { 22q11.21(1862481855_- } \\
\text { 21062134)x1 }\end{array}$ & Loss & $\begin{array}{l}22 \mathrm{q} 11.2 \\
\text { recur- } \\
\text { rent } \\
\text { (DGS/V } \\
\text { region } \\
\text { (proxi- } \\
\text { mal } \\
\text { A_B) } \\
\text { (in- } \\
\text { cludes } \\
\text { TBX1) }\end{array}$ & / & $\begin{array}{l}\text { de } \\
\text { novo }\end{array}$ & $\mathrm{P}$ & TOP \\
\hline 31 & $\begin{array}{l}\operatorname{chr} 18 q \\
\text { dup }\end{array}$ & $\begin{array}{l}\text { 18q22.1(642\$1861_- } \\
66769260) \times 3\end{array}$ & Gain & / & / & NA & VUS & NA \\
\hline 32 & $\begin{array}{l}\text { chr21q } \\
\text { dup }\end{array}$ & $\begin{array}{l}21 \mathrm{q} 22.3(439415821 \ldots \\
46523623) \times 3\end{array}$ & Gain & / & / & $\begin{array}{l}\text { Inherited } \\
\text { from } \\
\text { normal } \\
\text { mother }\end{array}$ & VUS & Born \\
\hline 33 & $\begin{array}{l}\text { chr22q } \\
\text { dup }\end{array}$ & $\begin{array}{l}\text { 22q11.21(1862676651_- } \\
21283290) \times 3\end{array}$ & Gain & $\begin{array}{l}22 \mathrm{q} 11.2 \\
\text { recur- } \\
\text { rent } \\
\text { (DGS/V } \\
\text { region } \\
\text { (proxi- } \\
\text { mal } \\
\text { A_B) } \\
\text { (in- } \\
\text { cludes } \\
\text { TBX1) }\end{array}$ & / & $\mathrm{NA}$ & $\mathrm{P}$ & TOP \\
\hline
\end{tabular}




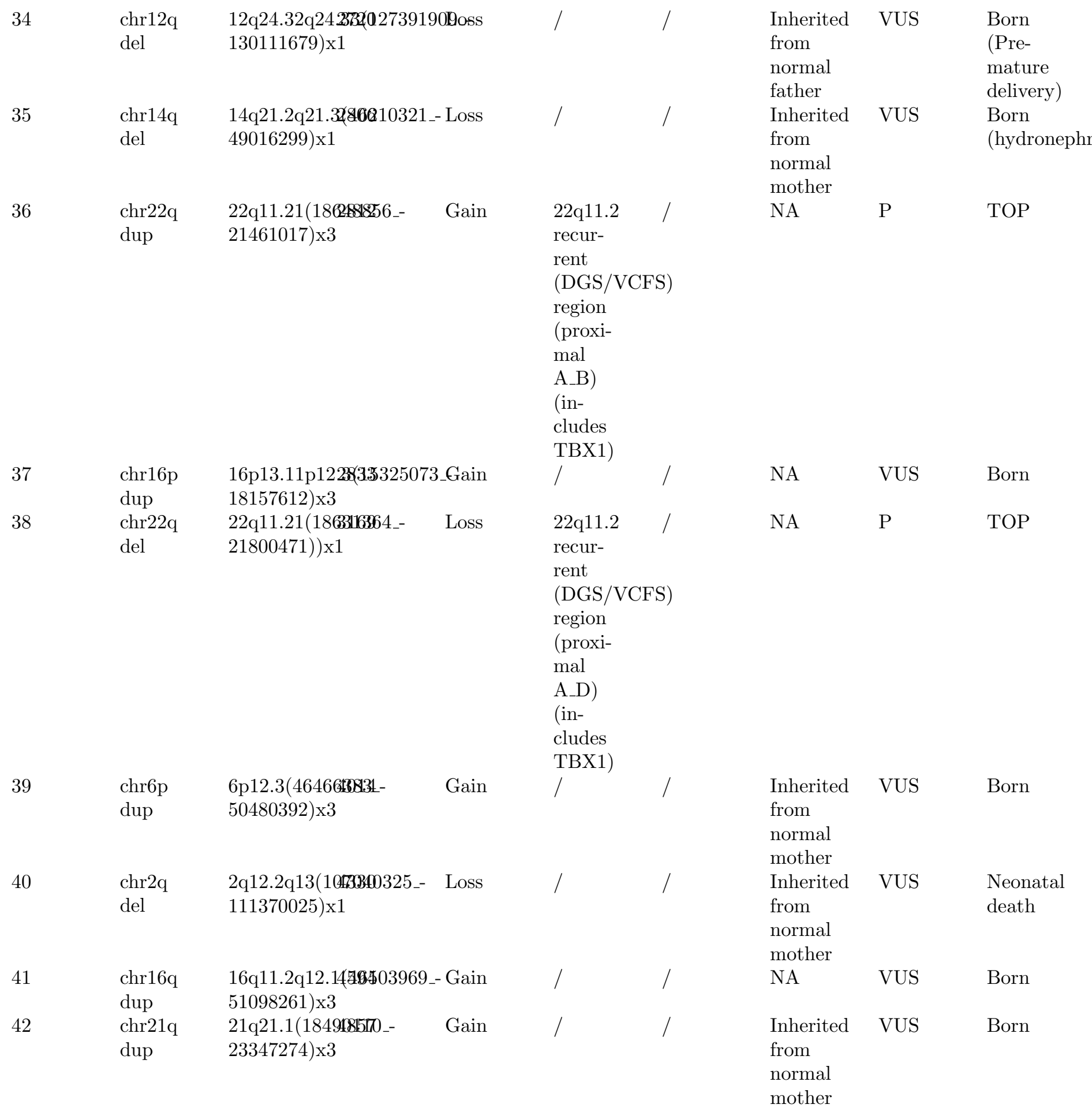




\begin{tabular}{|c|c|c|c|c|c|c|c|}
\hline 43 & $\begin{array}{l}\operatorname{chr} 15 q \\
\operatorname{dup}\end{array}$ & $\begin{array}{l}\text { 15q11.2q13.1493832678_- Gain } \\
\text { 28560664)x3 }\end{array}$ & $\begin{array}{l}15 q 11 q 13 \\
\text { recur- } \\
\text { rent } \\
(\mathrm{PWS} / \mathrm{AS}) \\
\text { region } \\
\left(\mathrm{BP} 2{ }_{-}\right. \\
\text {BP3 } \\
\text { Class } \\
2)\end{array}$ & / & $\begin{array}{l}\text { Inherited } \\
\text { from } \\
\text { normal } \\
\text { mother }\end{array}$ & $\mathrm{P}$ & Born \\
\hline 44 & $\begin{array}{l}\operatorname{chr} 5 q \\
\text { dup }\end{array}$ & $\begin{array}{l}\text { 5q22.1q23.1(329896866_- Gain } \\
\text { 116195651)x3 }\end{array}$ & j & / & NA & VUS & TOP \\
\hline 45 & $\begin{array}{l}\text { chr8q } \\
\text { dup }\end{array}$ & $\begin{array}{l}\text { 8q23.1q23.3(340273153_- Gain } \\
\text { 115684011)x3 }\end{array}$ & / & / & NA & VUS & Born \\
\hline 46 & $\begin{array}{l}\text { chr11p } \\
\text { dup }\end{array}$ & $\begin{array}{l}\text { 11p15.1p14.3(201)253705_- Gain } \\
\text { 25684613)x3 }\end{array}$ & / & / & $\begin{array}{l}\text { Inherited } \\
\text { from } \\
\text { normal } \\
\text { mother }\end{array}$ & VUS & Born \\
\hline 47 & $\begin{array}{l}\text { chr11p } \\
\text { dup }\end{array}$ & $\begin{array}{l}\text { 11p15.1p14.35(28)277669_- Gain } \\
\text { 25713381)x3 }\end{array}$ & / & / & $\begin{array}{l}\text { Inherited } \\
\text { from } \\
\text { normal } \\
\text { mother }\end{array}$ & VUS & Born \\
\hline 48 & $\begin{array}{l}\operatorname{chr} 10 \mathrm{q} \\
\text { del }\end{array}$ & $\begin{array}{l}\text { 10q11.22q11.2524 46293590Loss } \\
\text { 51817663)x1 }\end{array}$ & / & / & $\begin{array}{l}\text { Inherited } \\
\text { from } \\
\text { normal } \\
\text { mother }\end{array}$ & VUS & Born \\
\hline 49 & $\begin{array}{l}\operatorname{chr} 15 q \\
\text { dup }\end{array}$ & $\begin{array}{l}\text { 15q26.1q26.36.96404310_- Gain } \\
\text { 98968661)x3 }\end{array}$ & / & / & NA & VUS & Born \\
\hline 50 & $\begin{array}{l}\operatorname{chr} 16 \mathrm{p} \\
\text { del }\end{array}$ & $\begin{array}{l}\text { 16p13.13p1253698548052 Łoss } \\
\text { 18242713)x1 }\end{array}$ & $\begin{array}{l}16 \mathrm{p} 13.11 \\
\text { recur- } \\
\text { rent } \\
\text { region } \\
\text { (BP2_- } \\
\text { BP3) } \\
\text { (in- } \\
\text { cludes } \\
\text { MYH11) }\end{array}$ & / & NA & $\mathrm{P}$ & Born \\
\hline 51 & $\begin{array}{l}\operatorname{chr} 15 q \\
\operatorname{dup}\end{array}$ & $\begin{array}{l}\text { 15q11.2q13.152:2670421_- Gain } \\
\text { 28526905)x3 }\end{array}$ & $\begin{array}{l}15 q 11 q 13 \\
\text { recur- } \\
\text { rent } \\
(\mathrm{PWS} / \mathrm{AS}) \\
\text { region } \\
\left(\mathrm{BP} 1{ }_{-}\right. \\
\mathrm{BP} 3 \\
\text { Class } \\
1)\end{array}$ & / & $\begin{array}{l}\text { Inherited } \\
\text { from } \\
\text { normal } \\
\text { mother }\end{array}$ & $\mathrm{P}$ & NA \\
\hline 52 & $\begin{array}{l}\operatorname{chr} 12 q \\
\text { del }\end{array}$ & $\begin{array}{l}\text { 12q21.2q21.36(28313475_Loss } \\
\text { 85441579)x1 }\end{array}$ & j & PPP1R12A & NA & $\mathrm{P}$ & Born \\
\hline 53 & $\begin{array}{l}\text { chr8q } \\
\text { del }\end{array}$ & $\begin{array}{l}\text { 8q21.13q21.37(86275606_- Loss } \\
\text { 87340145)x1 }\end{array}$ & / & / & NA & VUS & TOP \\
\hline
\end{tabular}




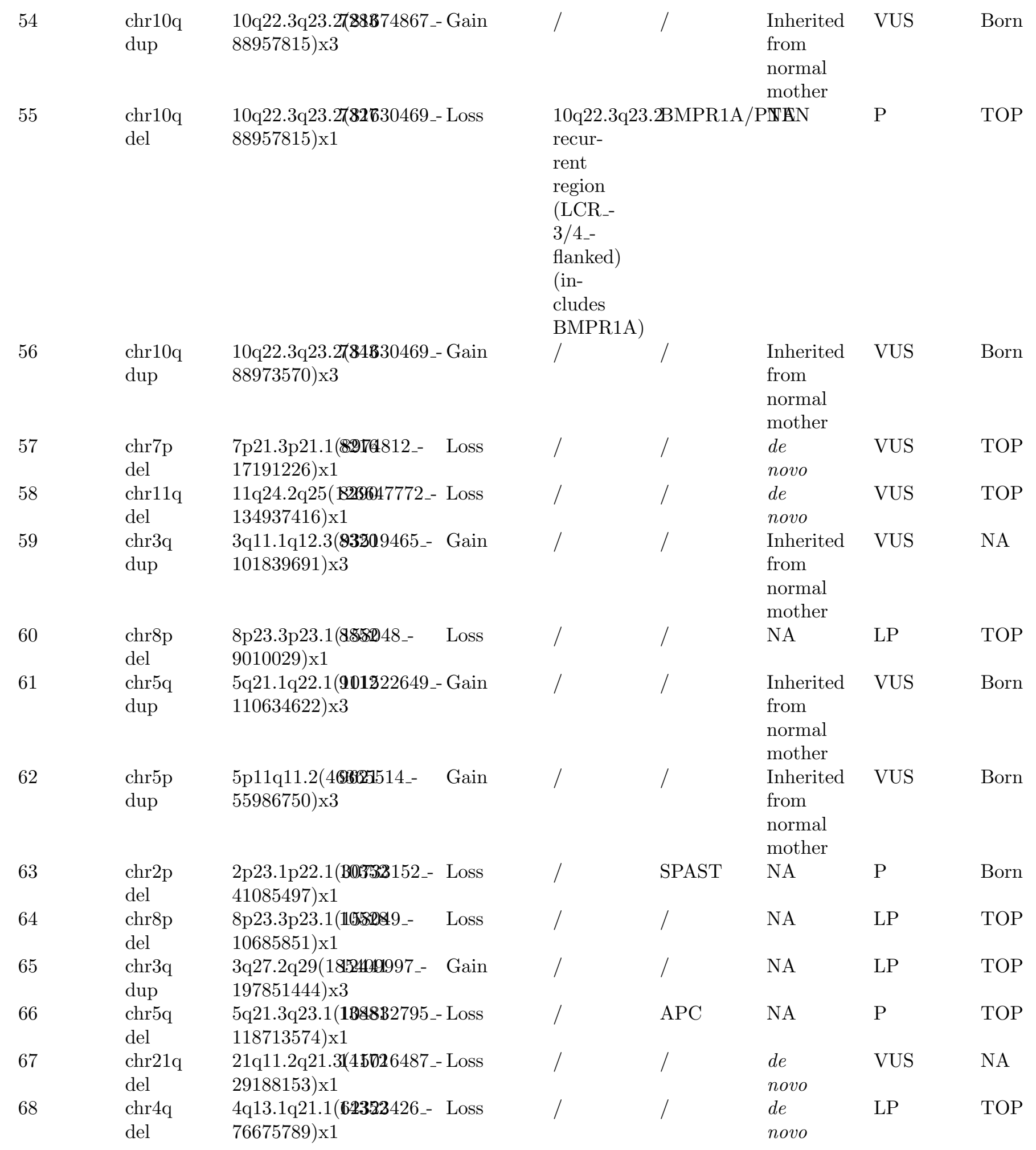




\begin{tabular}{|c|c|c|c|c|c|c|c|c|}
\hline 69 & $\begin{array}{l}\text { chr18q } \\
\text { del }\end{array}$ & $\begin{array}{l}\text { 18q22.1q23(613535361_- } \\
78013728) \times 1\end{array}$ & Loss & / & / & $\begin{array}{l}\text { Inherited } \\
\text { from } \\
\text { mother } \\
\text { with } \\
\text { intel- } \\
\text { lectual } \\
\text { disability }\end{array}$ & VUS & NA \\
\hline 70 & $\begin{array}{l}\text { chr18p } \\
\text { del }\end{array}$ & $\begin{array}{l}\text { 18p11.32(136226- } \\
1331930) \times 113827 \\
18 \mathrm{p} 11.32 \mathrm{p} 11.21(1343954 \\
15170636) \times 3\end{array}$ & $\begin{array}{l}\text { Loss } \\
\text { Gain } \\
\text {-- }\end{array}$ & / / & $1 /$ & NA NA & VUS LP & Born \\
\hline 71 & $\begin{array}{l}\text { chr18p } \\
\text { dup }\end{array}$ & $\begin{array}{l}\text { 18p11.32q23(158642828_- } \\
15181207) \times 2.15\end{array}$ & $\begin{array}{l}\text { Gain } \\
\text { (mosaic) }\end{array}$ & / & / & NA & $\mathrm{LP}$ & TOP \\
\hline 72 & $\begin{array}{l}\operatorname{chr} 2 q \\
\text { dup }\end{array}$ & $\begin{array}{l}\text { 2q23.3q31.1(162388188_- } \\
170720261) \times 3\end{array}$ & Gain & / & / & NA & $\mathrm{LP}$ & TOP \\
\hline 73 & $\begin{array}{l}\operatorname{chr} 5 p \\
\text { del }\end{array}$ & $\begin{array}{l}5 \mathrm{p} 15.33 \mathrm{p} 14.31\left(86 B 576_{-}-\right. \\
18727376) \times 1\end{array}$ & Loss & $\begin{array}{l}5 \text { p15 } \\
\text { termi- } \\
\text { nal } \\
\text { (Cri du } \\
\text { chat } \\
\text { syn- } \\
\text { drome) } \\
\text { region }\end{array}$ & TRIO & NA & $\mathrm{P}$ & TOP \\
\hline 74 & $\begin{array}{l}\text { chr4q } \\
\text { del }\end{array}$ & $\begin{array}{l}\text { 4q31.3q34.2(234881387_- } \\
176868942) \times 1\end{array}$ & Loss & l & / & NA & LP & TOP \\
\hline 75 & $\begin{array}{l}\text { chr5p } \\
\text { del }\end{array}$ & $\begin{array}{l}\text { 5p15.33p14.12(113)(577_- } \\
26243789) \times 1\end{array}$ & Loss & $\begin{array}{l}5 \mathrm{p} 15 \\
\text { termi- } \\
\text { nal } \\
\text { (Cri du } \\
\text { chat } \\
\text { syn- } \\
\text { drome) } \\
\text { region }\end{array}$ & TRIO & NA & $\mathrm{P}$ & TOP \\
\hline 76 & $\begin{array}{l}\text { chr18p } \\
\text { dup }\end{array}$ & $\begin{array}{l}\text { 18p11.22(8711813_- } \\
10139732) \times 31322 \\
22 q 11.23 q 12.1\left(25116001_{-}\right. \\
26437690) \times 3\end{array}$ & $\begin{array}{l}\text { Gain } \\
\text { Gain }\end{array}$ & $1 /$ & / / & $\begin{array}{l}\text { Inherited } \\
\text { from } \\
\text { normal } \\
\text { mother } \\
\text { de novo }\end{array}$ & $\begin{array}{l}\text { VUS } \\
\text { VUS }\end{array}$ & $\begin{array}{l}\text { TOP } \\
\text { (hydrocepha }\end{array}$ \\
\hline 77 & chr8p del & $\begin{array}{l}\text { 8p23.3p23.2(398B)48_- } \\
3220759) \times 169180 \\
8 \mathrm{q} 21.11 \mathrm{q} 24.3\left(77115706_{-}-\right. \\
146295771) \times 3\end{array}$ & $\begin{array}{l}\text { Loss } \\
\text { Gain }\end{array}$ & $1 /$ & / / & $\begin{array}{l}\text { Paternal } \\
\text { invertion: } \\
46, X Y, \text { inv }\end{array}$ & $\begin{array}{l}\text { VUS LP } \\
\text { 3)(p23.2;q21) }\end{array}$ & TOP \\
\hline 78 & chr8p del & $\begin{array}{l}\text { 8p23.3p23.2(458D48_- } \\
\text { 4745371)x1 22284 } \\
\text { 9p24.3p21.3(208454_- } \\
22492876) \times 3\end{array}$ & $\begin{array}{l}\text { Loss } \\
\text { Gain }\end{array}$ & $1 /$ & / / & $\begin{array}{l}\text { Maternal } \\
\text { balanced } \\
\text { translo- } \\
\text { cation: } \\
46, \mathrm{XX}, \mathrm{t}(8 ;\end{array}$ & $\begin{array}{l}\text { VUS LP } \\
\text { (p23;p21.3) }\end{array}$ & TOP \\
\hline
\end{tabular}




\begin{tabular}{|c|c|c|c|c|c|c|c|c|}
\hline 79 & $\begin{array}{l}\text { chr20p } \\
\text { dup }\end{array}$ & $\begin{array}{l}\text { 20p13p12.1(AB61686-- } \\
\text { 13546848)x310936 } \\
\text { 9p24.3p23(208455_- } \\
\text { 11144684)x1 }\end{array}$ & $\begin{array}{l}\text { Gain } \\
\text { Loss }\end{array}$ & 11 & / & $\begin{array}{l}\text { Paternal } \\
\text { balanced } \\
\text { translo- } \\
\text { cation: } \\
46, \mathrm{XY}, \mathrm{t}(9 ; 2\end{array}$ & $0)(\mathrm{p} 23 ; \mathrm{p} 12.1$ & TOP \\
\hline 80 & $\begin{array}{l}\operatorname{chr} 9 p \\
\text { dup }\end{array}$ & $\begin{array}{l}\text { 9p24.3p22.3(25) } \\
\text { 15608372)x31528 } \\
\text { 5p15.33(113577_- } \\
\text { 1641914)x1 }\end{array}$ & $\begin{array}{l}\text { Gain } \\
\text { Loss }\end{array}$ & 11 & 11 & $\begin{array}{l}\text { Inherited } \\
\text { from } \\
\text { mother } \\
\text { with in- } \\
\text { tellectual } \\
\text { disabil- } \\
\text { ity: } \\
46, X X \text {,der } \\
\text { t(5;9)(p15.3 }\end{array}$ & $\begin{array}{l}\text { VUS } \\
\text { VUS } \\
\\
\\
\\
\\
\\
\text {;p22) }\end{array}$ & TOP \\
\hline 81 & $\begin{array}{l}\text { chr12q } \\
\text { dup }\end{array}$ & $\begin{array}{l}\text { 12q24.21q24.13699267858 } \\
\text { 133777562)x3287 } \\
\text { 2q37.3(240495629_- } \\
242782258) \times 1\end{array}$ & $\begin{array}{l}\text { 8Qtain } \\
\text { Loss }\end{array}$ & 11 & / I & $\begin{array}{l}\text { Maternal } \\
\text { balanced } \\
\text { translo- } \\
\text { cation: } \\
46, \mathrm{XX}, \mathrm{t}(2 ; 1\end{array}$ & $\begin{array}{l}\text { LP VUS } \\
\text { 2)(q37;q24) }\end{array}$ & TOP \\
\hline 82 & $\begin{array}{l}\text { chr18q } \\
\text { dup }\end{array}$ & $\begin{array}{l}\text { 18q21.33q23(1671906988_- } \\
78013728) \times 33641 \\
\text { 4q35.2(187316147_- } \\
\text { 190957460)x1 }\end{array}$ & $\begin{array}{l}\text { Gain } \\
\text { Loss }\end{array}$ & / I & / I & $\begin{array}{l}\text { Inherited } \\
\text { from } \\
\text { mother } \\
\text { with in- } \\
\text { tellectual } \\
\text { disabil- } \\
\text { ity: } \\
46, X X \text {, der } \\
\text { t(4;18)(q35; }\end{array}$ & $\begin{array}{l}\text { VUS } \\
\text { VUS } \\
\\
\\
\\
; \text { q22) }\end{array}$ & TOP \\
\hline 83 & $\begin{array}{l}\text { chr17q } \\
\text { dup } \\
\text { chr11p } \\
\text { del }\end{array}$ & $\begin{array}{l}\text { 17q23.3q25.31 } 82665472_{-}- \\
\text {81041823)x32928 } \\
\text { 1p36.33p36.32(849466_- } \\
\text { 3777765)x1 }\end{array}$ & $\begin{array}{l}\text { Gain } \\
\text { Loss }\end{array}$ & $\begin{array}{l}\text { / } 1 \mathrm{p} 36 \\
\text { terminal } \\
\text { region } \\
\text { (includes } \\
\text { GABRD) }\end{array}$ & / / & $\begin{array}{l}\text { Maternal } \\
\text { balanced } \\
\text { translo- } \\
\text { cation: } \\
46, \mathrm{XX}, \mathrm{t}(1 ; 1\end{array}$ & $\begin{array}{l}\text { LP P } \\
\text { 7) (p36;q23) }\end{array}$ & TOP \\
\hline 84 & $\begin{array}{l}\text { chr18q } \\
\text { del }\end{array}$ & $\begin{array}{l}\text { 18q21.32q23(158910\%6726_- } \\
78013728) \times 11113 \\
\text { 1q43(238949246_-- } \\
240062389) \times 1\end{array}$ & Loss Loss & / / & / / & NA & LP VUS & TOP \\
\hline 85 & $\begin{array}{l}\text { chr9p } \\
\text { dup }\end{array}$ & $\begin{array}{l}\text { 9p24.3p13.2(2584286_- } \\
\text { 37055141)x31369 } \\
\text { 9p24.3(208454_- } \\
\text { 1577575)x1 }\end{array}$ & $\begin{array}{l}\text { Gain } \\
\text { Loss }\end{array}$ & / I & / / & NA & LP VUS & TOP \\
\hline 86 & $\begin{array}{l}\text { chr20p } \\
\text { dup }\end{array}$ & $\begin{array}{l}\text { 20p13p11.210411061_- } \\
\text { 24487341)x38545 } \\
\text { 11q24.2q25(126392021_- } \\
\text { 134937416)x1 }\end{array}$ & $\begin{array}{l}\text { Gain } \\
\text { Loss }\end{array}$ & / I & / I & $\begin{array}{l}\text { Maternal } \\
\text { balanced } \\
\text { translo- } \\
\text { cation: } \\
46, \mathrm{XX}, \mathrm{t}(11 ;\end{array}$ & 20)(q24.2;p1 & $1.2)$ \\
\hline
\end{tabular}


87

89

90

91

92

93

94

95

96

$\begin{array}{lll}\text { chr3p } & \text { 3p26.3p22.2(283857_- } & \text { Gain } \\ \text { dup } & \text { 37597219)x38637 } & \text { Loss } \\ & \text { 5p15.33p15.31(113577_- } & \\ & \text { 8750244)x1 } & \end{array}$

$\operatorname{chr} 14 \mathrm{q}$

del

chr7q

del

Yq11.21q11.7B0(1446077Løss 15220682)x0

16p11.2(294285131_- Loss 30190029)x1

$/ 5 \mathrm{p} 15 \quad /$ TRIO
terminal
(Cri du
chat syn-
drome)
region
$/$
$16 \mathrm{p} 11.2$

Paternal balanced

translocation:

46,XY,t(3;5)(p24;p15.3)

NA

VUS

Born

recur-

de

$\mathrm{P}$

novo

rent

region

(proxi-

mal

BP4_-

BP5)

(in-

cludes

TBX6)

chr1p 4q35.2(190118mB5 5 - $\quad$ Loss

del 190957460)x1

/

l

NA

VUS

Born

chr4q

dup

$\operatorname{chr} 15 q$

10p13p12.33(1EZ2066844_- Gain

dup

18286639)x3

/

Inhe

from

normal

mother

Xp22.3
recur-

STS

NA

$\mathrm{P}$

Born

del 8143509)x1

rent

region

(in-

cludes

\begin{tabular}{|c|c|}
\hline $\begin{array}{l}\text { chr18p } \\
\text { dup } \\
\text { chr5q } \\
\text { dup }\end{array}$ & $\begin{array}{l}\text { 4q34.3(178131(12011_- } \\
179860825) \times 3 \\
8 \mathrm{q} 24.12\left(1197250530_{-}\right. \\
122337637) \times 3\end{array}$ \\
\hline $\begin{array}{l}\text { chr11p } \\
\text { del }\end{array}$ & $\begin{array}{l}\text { 1q25.3q31.1(284825946_- } \\
\text { 187563410)x1 }\end{array}$ \\
\hline $\begin{array}{l}\text { chr14q } \\
\text { dup }\end{array}$ & $\begin{array}{l}\text { 5p15.1p14.3(3297900_- } \\
21148212) \times 3\end{array}$ \\
\hline
\end{tabular}

STS)

NA

VUS

Born

Inherited VUS Born

from

normal

father

Inherited VUS Born

from

normal

mother

Inherited VUS Born

from

normal

mother 
CNV: pathogenic copy_number variant; CMA: chromosomal microarray analysis; NIPS: noninvasive prenatal screening; HI: haploinsufficiency; TS: triplosensitivity; ACMG: American College of Medical Genetics and Genomics; NA: not available; P: pathogenic; LP: likely pathogenic; VUS: uncertain clinical significance; TOP: termination of pregnancy

Table 4 Prenatal ROHs detected by CMA among the 528 gravidas with positive NIPS results

\begin{tabular}{|c|c|c|c|c|c|c|}
\hline No. & NIPS & $\begin{array}{ll}\text { CNVs } & \text { Size of } \\
(\text { GRCh37) } & \begin{array}{l}\text { ROHs } \\
(\mathrm{kb})\end{array}\end{array}$ & $\begin{array}{l}\text { Copy } \\
\text { number }\end{array}$ & Disorder & Source & Outcomes \\
\hline 98 & chr1 dup & $\begin{array}{l}\text { 1p36.33p11.2(8896558- } \\
121339317) \quad 120451 \\
\text { hmz } \\
1 q 21.2 q 44\left(149879544_{-}-\right. \\
249198164) \\
\text { hmz }\end{array}$ & $\begin{array}{l}\text { UPD1 } \\
\text { (isodisomy) }\end{array}$ & / & NA & TOP \\
\hline 99 & chr1 del & $\begin{array}{l}\text { 1p36.33p11.2(8896509- } \\
121339317) \quad 120451 \\
\text { hmz } \\
1 q 21.2 q 44\left(149879544_{-}-\right. \\
249198164) \\
\text { hmz }\end{array}$ & $\begin{array}{l}\text { UPD1 } \\
\text { (isodisomy) }\end{array}$ & / & NA & TOP (FGR) \\
\hline 100 & chr1dup & $\begin{array}{l}\text { 1p36.33p11.2(88965589- } \\
121339317) \quad 120451 \\
\text { hmz } \\
\text { 1q21.2q44(149879544_- } \\
249198164) \\
\text { hmz }\end{array}$ & $\begin{array}{l}\text { UPD1 } \\
\text { (isodisomy) }\end{array}$ & / & NA & $\begin{array}{l}\text { Born } \\
\text { (Methyl- } \\
\text { malonic } \\
\text { acidemia) }\end{array}$ \\
\hline 101 & chr2 del & $\begin{array}{l}2 \mathrm{p} 25.3 \mathrm{p} 11.2(50812002 \\
87053152) \quad 147223 \\
\mathrm{hmz} \\
2 \mathrm{q} 11.1 \mathrm{q} 37.3\left(95550957_{-}\right. \\
242773583) \\
\mathrm{hmz}\end{array}$ & $\begin{array}{l}\text { UPD2 } \\
\text { (isodisomy) }\end{array}$ & / & NA & TOP (FGR) \\
\hline 102 & chr2 dup & $\begin{array}{l}2 \mathrm{p} 25.3 \mathrm{p} 11.2(508913002 \\
87053152) \quad 147223 \\
\mathrm{hmz} \\
2 \mathrm{q} 11.1 \mathrm{q} 37.3\left(95550957_{-}-\right. \\
242773583) \\
\mathrm{hmz}\end{array}$ & $\begin{array}{l}\text { mUPD2 } \\
\text { (isodisomy) }\end{array}$ & / & maternal & $\begin{array}{l}\text { TOP } \\
\text { (hydrops } \\
\text { fetalis) }\end{array}$ \\
\hline
\end{tabular}


chr2 dup$$
\mathrm{hmz}
$$

104

chr3 dup

3q11.1q13.11(935587255

105429152) 13985

hmz

3p26.3p25.1(73602_-

16294894)

hmz

3p12.3p11.1(74601403_-

88586090)

hmz

105

chr4 dup

4p16.3p11(751728988

49063479) $\quad 138225$

hmz

4q11q35.2(52696791_190921709)

$\mathrm{hmz}$

106

chr4 del

4p16.3p11(751728988

49063479) 138225

$\mathrm{hmz}$

4q11q35.2(52696791_-

190921709)

hmz

107

chr4 dup

4p16.3p11(751728988

49063479) 138225

$\mathrm{hmz}$

4q11q35.2(52696791_-

190921709)

hmz

108

chr4 dup

4p16.3p15.33(751150346 10358
$15121280) \quad 47727$

$\mathrm{hmz}$

4p14p11(38705256_-

49063479)

$\mathrm{hmz}$

4q28.2q34.2(129685157_-

177412472)

hmz

109
$6 \mathrm{p} 25$

$58726706) \quad 108924$

$\mathrm{hmz}$

6q11.1q27(61972917_-

170896644)

hmz maternal Born

(iso_-

heterodisomy)

maternal NA

(iso_-

heterodisomy)

\section{UPD4}

NA

TOP

(isodisomy)

pUPD4

(isodisomy)

paternal

TOP (FGR)

UPD4

(isodisomy)

NA

Born

mUPD4 /

(iso_-

heterodisomy)

pUPD6
(isodisomy)

Transient

Neonatal

Diabetes

mellitus

(TNDM) maternal TOP

paternal 


$$
\text { chr6 del }
$$

112

113

114

115

116

117$$
\text { chr7 dup }
$$

$$
\begin{aligned}
& 6 \mathrm{p} 2 \\
& 587 \\
& \mathrm{hm} \\
& 6 \mathrm{q} \\
& 170 \\
& \mathrm{hm} \\
& 6 \mathrm{p} 2 \\
& 587 \\
& \mathrm{hm} \\
& 6 \mathrm{q} \\
& 1708
\end{aligned}
$$$$
\text { hmz }
$$$$
\text { 6p241p11.1(1330rom }
$$$$
\text { 5824.1p11.1(1334533 }
$$$$
5872
$$$$
\text { 6q16.1q22.31(94446431_- }
$$$$
\text { 124307093) }
$$$$
\mathrm{hmz}
$$$$
\text { 6q25.1q27(150710446_- }
$$$$
\text { 170896644) }
$$$$
\mathrm{hmz}
$$$$
\text { 6p25.3p11.1(203 }
$$$$
\begin{array}{ll}
58726706) \quad & 108924 \\
\text { hmz }
\end{array}
$$$$
\text { 6q11.1q27(61972918_- }
$$$$
\text { 170896644) }
$$$$
\text { hmz }
$$$$
\text { 7p22.3p11.1(509515969 } 96549
$$$$
\text { 58019983) }
$$$$
\mathrm{hmz}
$$$$
\text { 7q11.21q36.3(62569501_- }
$$$$
\text { 159118443) }
$$$$
\text { hmz }
$$

mUPD6

(isodisomy)
UPD6

(isodisomy)
NA

TOP

mUPD6 /

(isodisomy)

maternal

maternal

NA

(isodisomy)

UPD7

(isodisomy)

NA

TOP

mUPD8 /

(isodisomy)

UPD8

(isodisomy)

NA

maternal TOP

TOP
Born (short stature) 


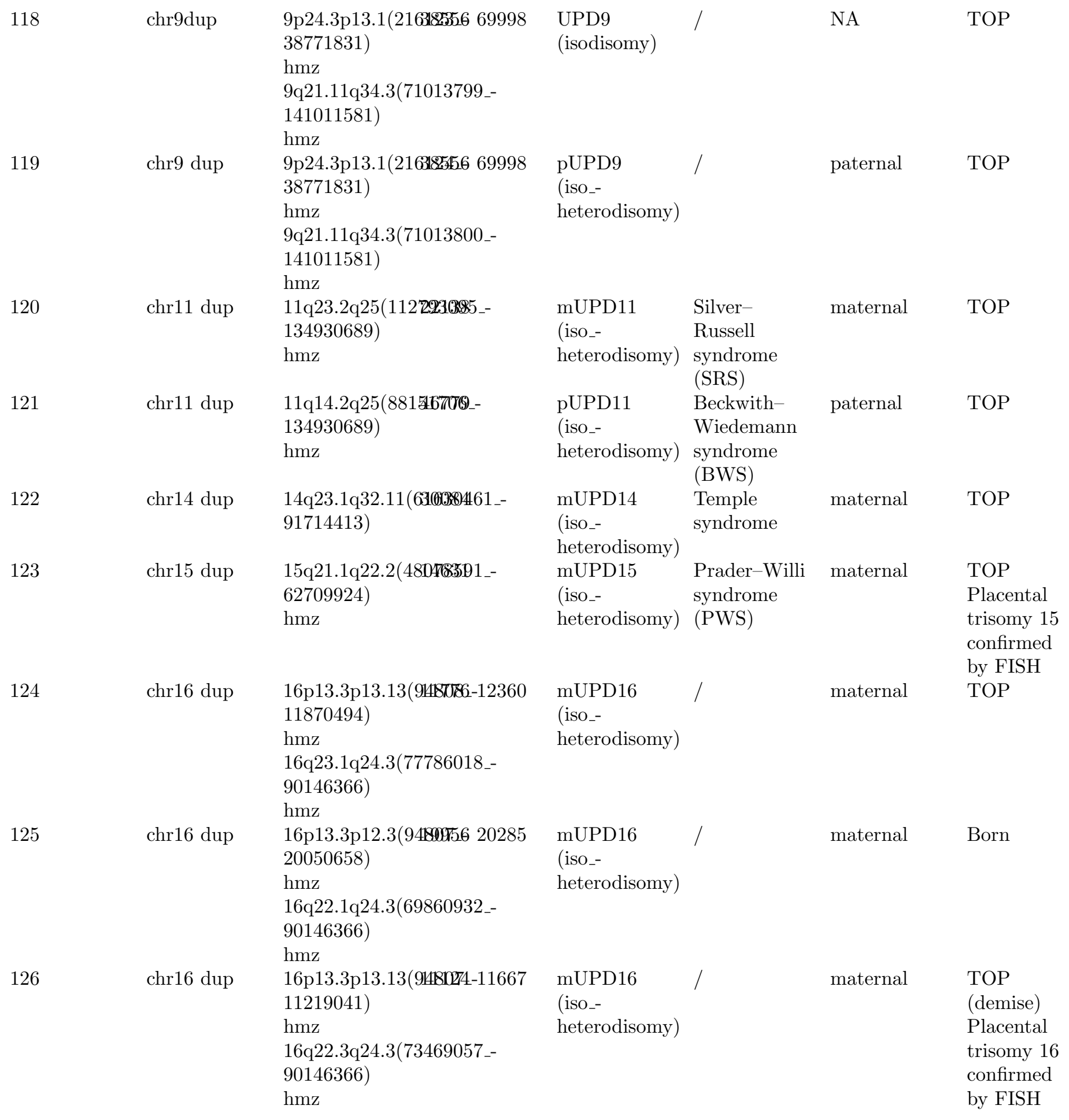


chr17 del

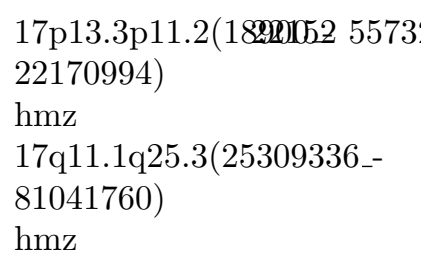

NA

Born

NA

NA

NA

Born

NA

Born (short stature)

NA

Neonatal death

2p12p11.2(75698T.BS4 $10624 \quad \mathrm{ROH}$ 87053152)

hmz

2q11.1q12.2(95550957_106174659)

hmz 


$$
\text { chr3 dup }
$$

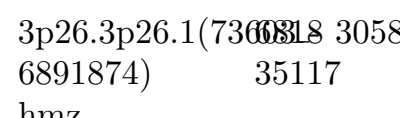

$\mathrm{ROH}$

$\mathrm{ROH}$

$\mathrm{ROH}$

NA

NA

NA

Born

NA

$\mathrm{ROH}$

NA

Born 


\begin{tabular}{|c|c|c|c|c|c|c|}
\hline 144 & chr16 dup & $\begin{array}{l}16 \mathrm{p} 13.3 \mathrm{p} 13.12(91309- \\
14053831) \\
\mathrm{hmz}\end{array}$ & $\mathrm{ROH}$ & / & NA & TOP \\
\hline 145 & chr16 dup & $\begin{array}{l}16 \mathrm{p} 13.3 \mathrm{p} 12.3(94892836 \\
19331243) \\
\mathrm{hmz}\end{array}$ & $\mathrm{ROH}$ & / & NA & Born \\
\hline 146 & chr16 dup & $\begin{array}{l}16 \mathrm{p} 13.3\left(94808_{-}-70598206\right. \\
7154181) \\
\text { hmz } \\
\text { 16q23.3q24.3(81940867_- } \\
90146366) \\
\text { hmz }\end{array}$ & $\mathrm{ROH}$ & / & NA & Born \\
\hline 147 & chr16 dup & $\begin{array}{l}\text { 16p13.3(94808_-5405 } 16958 \\
5500174) \\
\text { hmz } \\
\text { 16q21q23.3(66159040_- } \\
83117017) \\
\text { hmz }\end{array}$ & $\mathrm{ROH}$ & / & NA & $\begin{array}{l}\text { fetal loss } \\
\text { after } \\
\text { amniocentesis }\end{array}$ \\
\hline
\end{tabular}

CMA: chromosomal microarray analysis; NIPS: noninvasive prenatal screening; UPD:uniparental disomy; ROH: regions of homozygosity; NA: not available; TOP: termination of pregnancy; FGR: fetal growth restriction; LVOTO: left ventricular outflow tract; FISH: fluorescence in situ hybridization

Table 5 Clinical follow-up assessment of the 528 fetuses detected by CMA

\begin{tabular}{|c|c|c|c|c|c|c|c|c|}
\hline \multirow[t]{2}{*}{$\begin{array}{l}\text { SNP- } \\
\text { array }\end{array}$} & $\begin{array}{l}\text { SNP- } \\
\text { array }\end{array}$ & Total & $\begin{array}{l}\text { Loss of } \\
\text { follow- } \\
\text { up }\end{array}$ & TOP & TOP & TOP & Birth & Birth \\
\hline & & & & \multicolumn{3}{|c|}{$\begin{array}{l}\text { Chromosomallltrasound Other } \\
\text { abnormalitiesbnormalities }\end{array}$} & Normal & $\begin{array}{l}\text { Birth } \\
\text { defect }\end{array}$ \\
\hline $\begin{array}{l}\text { Rare } \\
\text { aneuploidies }\end{array}$ & & 7 & - & 7 & - & - & - & - \\
\hline \multirow[t]{2}{*}{$\begin{array}{l}\text { Segmental } \\
\text { imbalances }\end{array}$} & $\begin{array}{l}\mathrm{P} / \mathrm{LP} \\
\mathrm{CNVs}\end{array}$ & 35 & 1 & 26 & - & - & 8 & - \\
\hline & VUS & 62 & 4 & 7 & 1 & - & 49 & - \\
\hline \multirow[t]{2}{*}{$\mathrm{ROH} / \mathrm{UPD}$} & UPD & 30 & 1 & 14 & 7 & 1 & 5 & 2 \\
\hline & $\mathrm{ROH}$ & 20 & 3 & 3 & 1 & 1 & 10 & 1 \\
\hline Normal & & 374 & 43 & - & 6 & 2 & 314 & 9 \\
\hline
\end{tabular}

CMA: chromosomal microarray analysis; SNP: single-nucleotide polymorphism; TOP: termination of pregnancy; P: pathogenic; LP: likely pathogenic; VUS: uncertain clinical significance; UPD:uniparental disomy; $\mathrm{ROH}$ : regions of homozygosity 


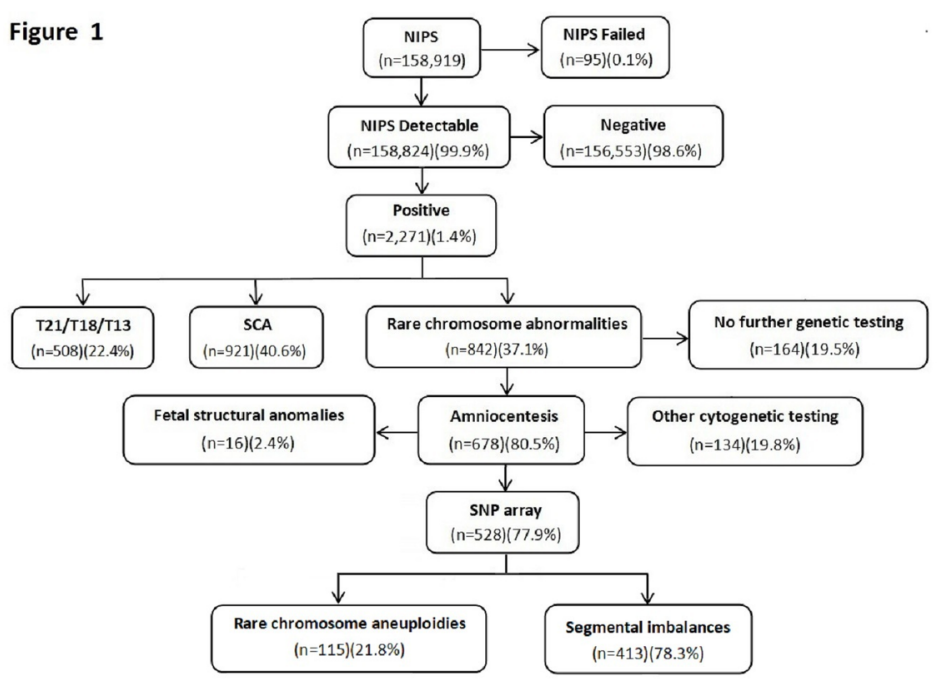

